\title{
Female faces in informal 'spaces': Women and artisanal and small-scale mining in sub-Saharan Africa
}

\author{
Gavin Hilson ${ }^{A^{*}}$, Abigail Hilson ${ }^{B}$, Agatha Siwale ${ }^{C}$ and Roy Maconachie ${ }^{D}$ \\ A Surrey Business School, University of Surrey, Guildford, Surrey, United Kingdom \\ B School of Management, Royal Holloway, University of London, Egham, Surrey, United Kingdom \\ ${ }^{\mathrm{C}}$ Central European University, Doctoral School of Political Science, Public Policy, and International \\ Relations, H-1051 Budapest, Nádor utca 9. Hungary \\ ${ }^{D}$ Centre for Development Studies, University of Bath, Bath, BA2 7AY, United Kingdom
}

*Email: g.m.hilson@surrey.ac.uk 


\begin{abstract}
This paper critically examines how women employed in artisanal and small-scale mining (ASM)-lowtech mineral extraction and processing-in sub-Saharan Africa could be affected by moves made to formalize and support their activities under the Africa Mining Vision (AMV), 'Africa's own response to tackling the paradox of great mineral wealth existing side by side with pervasive poverty'. One of the main goals of the AMV is Boosting Artisanal and Small-Scale Mining, which requires signatories to devise strategies for 'Harnessing the potential of small scale mining to improve rural livelihoods and integration into the rural and national economy'. Moves being made to achieve this, however, could have an adverse impact on many of the women working in ASM in sub-Saharan Africa. Findings from the literature and research being undertaken by the authors in Sierra Leone and Zambia suggest that whilst most women engaged in ASM in the region work informally and as a result, face very challenging circumstances daily, many have adapted to their surroundings and now generate far more money than they would earn from any other income-earning activity. Governments must study these dynamics before taking action under the auspices of the AMV to formalize and support women in ASM.
\end{abstract}

Keywords: artisanal and small-scale mining (ASM); sub-Saharan Africa; informal sector; women; poverty 


\section{Introduction}

In recent years, artisanal and small-scale mining (ASM) - low-tech, labour-intensive mineral extraction and process - has become an indispensable income-earning activity in hundreds of rural and periurban localities across sub-Saharan Africa. Precise workforce data are unavailable but based on compilations of individual country estimates, ASM employs at least 20 million people in the region, and has created income-earning opportunities for an additional 100-150 individuals. In sharp contrast to the messages conveyed in early policy documents and literature (e.g. Alpan, 1986; Noetstaller, 1987), which portrayed ASM as an activity pursued and populated by mostly opportunistic, and at times, rogue, entrepreneurs, more recent research (e.g. Maconachie and Binns, 2007; Kamlongera, 2011) has shown that, throughout sub-Saharan Africa, revenue from the sector's operations are relied upon heavily economically at the local level. The disposable income generated is used by families to cover, inter alia, their household expenses such as school fees and funeral costs, and to support other economic activities such as farming. The sector also accounts for a sizable share of the region's mineral production, including 18 percent of its gold, most of its cobalt, 15-20 percent of its diamonds and nearly all of its coloured gemstones (African Union, 2009). ${ }^{1}$

The rapid proliferation of ASM activities in some of the world's poorest environments, along with their ability to absorb individuals facing extreme hardship, has fittingly earned the sector the label 'povertydriven activity'. This observation was first made publicly in an international forum more than two decades ago, at the World Bank-hosted International Roundtable on Artisanal Mining in Washington DC, May 1995 (Barry, 1996). Whilst the poverty-driven narrative in ASM may be well-worn, it cannot be avoided in sub-Saharan Africa: here, asking individuals why they are mining would, in most cases, elicit a response such as 'because there are no jobs' or something very similar. There are, nevertheless, calls for scholarship to 'transcend' the poverty-driven narrative and debates on the links between personal hardship and ASM's growth more generally. One of the more vocal critics has been Verbrugge (2016), who claims that 'Indeed, whereas people's initial involvement in ASM is usually driven by poverty and subsistence needs, there is a growing recognition that the sector can serve as a platform for wealth creation' (p. 109). The insinuation here seems to be that discussions on ASM should focus less on personal hardship and concentrate more on the behaviours and actions of individuals who are currently working in the sector, in particular, determining how this work has transformed their livelihoods for the better. But whilst there is evidence which suggests that - at least in the case of sub-Saharan Africa - many of the people now engaged in ASM who have grown more comfortable with their surroundings use the sector creatively as a platform for wealth creation (see e.g. Werthmann, 2009; Hilson and Garforth, 2013), it does not change, nor should it detract attention from, the circumstances which drove them to mine in the first place. Doing so risks dismissing the bigger development challenges - for example, burgeoning youth unemployment and the deteriorating quality of education - plaguing sub-Saharan Africa and which drive individuals to mine here in the first place.

Verbrugge (2016) furthermore implies that people who engage in ASM are well-positioned to accumulate wealth, claiming that, 'In short, by stimulating a decentralization of markets...ASMexpansion creates opportunities for a heterogeneous group of actors that are able to capitalize on the

\footnotetext{
${ }^{1}$ This is consistent with the data available for ASM production worldwide, which underscore its economic importance of the sector across the developing world. Although the data are mostly outdated, there is reason to believe, despite its low productivity in most instances, that ASM accounts for roughly 20 percent of the global gold supply, 80 percent of the global sapphire supply and 20 percent of global diamond supply. It also accounts for a significant share of the world's output of industrial minerals, including 25 percent of its tantalum and 25 percent of its tin (IGF, 2017).
} 
increased and more diverse demands of the mining community' (p. 109). The reality in sub-Saharan Africa, however, is very different. As Fisher et al. (2009) suggests, the trajectories of those who turn to ASM for their livelihoods in the region and ultimately, their fates, are by no means predetermined nor forecastable. At the one extreme, explain the authors, 'individual miners and mining households may have been poor in the past but are not necessarily poor today', whilst 'conversely', at the other extreme, 'they may have the potential to fall into poverty in the future' (p. 33). This unpredictability is linked to the sector's deeply-rooted informality: over 95 percent of individuals engaged in ASM in sub-Saharan Africa could be operating without the requisite licenses and permits. The informal 'spaces' in which they are found are generally unmonitored by host governments, and in the absence of a regulatory presence, come under the control of a host of local-level actors such as chiefs, police and various middlemen (Hinton, 2005; Garrett, 2008; Buxton, 2013).

When analyzing more closely the dynamics of these informal 'spaces' in sub-Saharan Africa, it becomes clear how a sizable share of those engaged in ASM in the region have agricultural backgrounds, which a number of studies have shown over the years (e.g. Mondlane, 2003; Maconachie and Binns, 2007; Pijpers, 2011; Kamlongera, 2011). 'Transcending' what Verbrugge (2016) describes as 'this narrow focus on farming' (p. 109), however, is also impossible because these farmers, along with others from different segments of society (see e.g. UNECA, 2003; Banchirigah, 2006), have moved into the sector because, in a globalizing world, their preferred occupations are either no longer available or incapable of sustaining them in the current economic environment. The migration of this 'heterogeneous' group of actors into ASM hardly seems to be linked to a desire to capitalize on economic opportunities, as Verbrugge (2016) suggests is commonplace in the sector but is rather more reminiscent of change made out of necessity. When the movement of people into ASM communities is examined temporally in the way Hilson (2010) describes, individual motivations for turning to the sector for work can be more readily disaggregated. This includes, foremost, differentiating between examples of the opportunistic entrepreneurship which Verbrugge (2016) and others describe on the one hand, and on the other hand, cases where this income diversification has taken place more out of necessity and, in what can best be described as 'making the best out of their situations', individuals subsequently use their improved job security to pursue other ventures.

Growing international interest in large-scale mine development and the implementation of strict standards that demand traceability throughout mineral supply chains has put the informal ASM 'spaces' in sub-Saharan Africa into the global spotlight. Most recently, they have become a major focus of the Africa Mining Vision (AMV), 'Africa's own response to tackling the paradox of great mineral wealth existing side by side with pervasive poverty', which 'was adopted by Heads of State at the February 2009 AU summit following the October 2008 meeting of African Ministers responsible for Mineral Resources Development'. One of its core objectives is Boosting Artisanal and Small-Scale Mining, or 'Harnessing the potential of ASM to improve rural livelihoods, to stimulate entrepreneurship in a socially responsible manner, to promote local and integrated national development as well as regional cooperation' (African Mining Vision, 2009, p. 1). The architects of the AMV - African ministers in charge of mining - agree that this can be achieved through implementing policies and interventions which emphasize 'Improvement in the viability, progressivity and sustainability of the artisanal and small-scale subsector to enhance its contribution to growth and development through gaining access to training, extension services, finance, marketing and cleaner, efficient technologies' (UNECA, 2017a, p. 6). This assumes, however, that a regulatory and support structure 'that harnesses the potential of artisanal and small-scale mining to stimulate local and national entrepreneurship, improve livelihoods and advance integrated rural social and economic development' (UNECA, 2017a, p. 2) is in the best interests of all individuals working in the region's informal ASM 'spaces'. Hilson et al. (2018) drew attention to this potential pitfall, arguing that, in sub- 
Saharan Africa, ushering in a blueprint for ASM development in line with what the architects of the AMV prescribe could yield policies which 'assume' that the entrepreneurial spirts and aspirations of those working informally in the sector are similar. This would undoubtedly spawn inappropriate 'onesize-fits-all' interventions.

The purpose of this article is to build on this discussion by reflecting critically on how, in their efforts to create a policy environment that 'harnesses the potential of artisanal and small-scale mining to stimulate local and national entrepreneurship, improve livelihoods and advance integrated rural social and economic development' (African Union, 2009, p. v), host African governments could unintentionally further marginalize the more vulnerable groups now rooted in the region's informal ASM economy. On the one hand, in providing guidance to host governments on how to formalize and support ASM, the architects of the AMV very importantly have shown surprising creativity without detracting from the main policy concerns:

Countries should recognize the need to embed artisanal and small-scale mining policy into a broad rural development strategy, taking into account the poverty cycle that limits the development of the artisanal and small-scale mining subsector in Africa. Artisanal and smallscale mining interventions should also target increasing the viability of all types of mining operations...[UNECA, 2012, p. 23]

But on the other hand, there is always a risk, when pursuing any national-level objective aimed at facilitating change at the grassroots - in this case, to 'stimulate local and national entrepreneurship [in ASM]' - of overlooking micro-level dynamics and consequently generalizing about the needs of highly-heterogeneous populations. Emphasis, therefore, should be placed on gathering details about the organizational structures of informal ASM 'spaces' in sub-Saharan Africa and the people who populate them, including more insight into their initial motivations for pursuing work in this sector.

The paper helps to bridge this gap by focusing on women, who are generally portrayed as 'hav[ing] specific and unique roles in ASM, which can create unique health and safety risks in artisanal and small-scale mining' (Eftimie et al., 2009, p. 2), and as being among the more marginalized groups of individuals working in the sector, particularly in sub-Saharan Africa (see e.g. Yakovleva, 2007; Kelly et al., 2014). Whilst the AMV itself is not particularly prescriptive on the topic of gender, the Sustainable Development Goals (SDGs), adopted in 2015 as a blueprint for ending poverty, protecting the planet and ensuring prosperity for all over the next 15 years, are. Gender is a point of emphasis across all 17 of the goals and is also encapsulated entirely, thematically, in Goal 5, 'Gender Equality', the result of 'the sustained efforts of women's groups, UN Women and other gender equality champions' (Dhar, 2018 , p. 54). Whilst critics have been quick to point out how only one of the 17 SDGs focuses on gender compared to one out of eight of the Millennium Development Goals (MDGs), their predecessors (Kim, 2017), the former are seen as more comprehensive, engaging, and interconnected and under Goal 5 itself, a multidimensional approach has been adopted which touches on, and has created synergies with, all of the other goals. On the one hand, the more siloed MDGs and their main manifestations, including the Millennium Villages and Millennium Accounts, appeared to be in perpetual pilot test mode, sporting the look of an experiment. On the other hand, the SDGs have carried an aura of invincibility since their ratification by some 193 member states on 25 September 2015, at the start of a three day summit held at UN Headquarters in New York, which 'was bathed in 17 different colours, each colour representing a goal, turning the iconic building into a dazzling spectacle' (Ighobor, 2015, p. 4). Championing a motto of 'Leaving No-One Behind', the SDGs, Esquivel and Sweetman (2016) explain, 'will form a significant element in the constellation of international agreements which will shape the world for women in the next decade and a half' (p. 2). Goal 5 will inevitably reshape the outlooks, agendas and policies of gender ministries throughout the region. 
Can an AMV, implemented under the auspices of the SDGs, provide adequate guidance for designing frameworks and support structures that are in tune with the needs of women engaged in ASM in subSaharan Africa? Both certainly provide some direction on this front but with so little information about the sector's informal ASM 'spaces', host governments are not well-positioned to design programs capable of connecting with, let alone empowering and improving the wellbeing of, specific segments of the ASM workforce, including women. The discussion that follows builds a case for studying more closely the dynamics of the region's informal ASM economy, with a view toward using this information to develop programs that appropriately service the needs of groups such as women and which speak to the objectives enshrined in the country-level programs implemented under the auspices of the SDGs and AMV. The paper begins by examining the region's sizable informal economy, the growth of which officials tasked with conceiving country-level action plans to operationalize both policy interventions lack a comprehensive understanding of. This discussion is used to frame more detailed analysis of the drivers fuelling the expansion of informal ASM activities in the region, and to reflect critically on the efficacy of moves made to bring the sector's operators into the legal domain. Section 3 pulls together findings from research which details women's involvement in ASM in sub-Saharan Africa, the challenges they face and the importance of this work to their livelihoods. It raises questions about whether the formalization and gender empowerment agendas of the AMV and the SDGs, respectively, are capable of even reaching these women, let alone supporting them. Section 4 builds on this analysis, drawing on ongoing research in Sierra Leone and Zambia, work which illustrates the resilience of many of the women who pursue income-earning opportunities in ASM out of necessity in sub-Saharan Africa. In each case, through hard work, women have found an equilibrium in constrictive and at times, volatile, informal ASM 'spaces', albeit with limited opportunities for progression. But in the absence of fine-tuned interventions, designed specifically with the details of these work environments in mind, the livelihoods of female ASM operators could be disrupted by changes ushered in under the auspices of the AMV and SDGs. The paper concludes by prescribing ways in which to further support these women through policies and programs which speak to the AMV and SDG machinery.

\section{The Informal Economy of Sub-Saharan Africa in Context}

A burgeoning informal sector has become a hallmark of sub-Saharan Africa. The reach of the informal economy in sub-Saharan Africa seems limitless: according to the International Labour Organization (ILO), it provides two-thirds of its non-agricultural employment. ${ }^{2}$ Throughout the region, women tend to disproportionately work in the informal economy, in many cases, undertaking precarious and arduous work (Chen, 2008). Facing what at times seem to be impossible conditions, most of these women run what is referred to in the literature as 'household enterprises', ${ }^{3}$ showing enormous courage, commitment and business acumen in a bid to cater for their families, typically balancing this work with their family responsibilities.

If the SDGs are going to make headway in improving the lives of those employed in the informal sector in sub-Saharan Africa, the policies and interventions they spawn must be fine-tuned to the needs of the audiences in question, in this case the women employed in the ASM sector. Commenting generally on gender-based rights and economic status continent-wide, Hallward-Driemeier and Hasan (2013)

\footnotetext{
2 'Five Facts about Informal Economy in Africa', http://www.ilo.org/addisababa/whatsnew/WCMS 377286/lang--en/index.htm (Accessed 4 June 2018).

${ }^{3}$ Family farming and very small non-farm enterprises are commonly called 'informal enterprises'.
} 
argue that in sub-Saharan Africa, 'Property rights and legal capacity shape a woman's ability to engage in economic activity' (p. 16). The general consensus is that in all corners of the region, women face considerable restrictions when it comes to securing work, which ultimately push many into the informal economy. According to the World Bank, 43 percent, 51 percent and 9 percent of economies in sub-Saharan Africa have restrictions on women's employment, respectively, in 1) 'Jobs deemed hazardous, arduous or morally inappropriate', 2) particular industries and 3) night work (World Bank, 2018).

Can an effective gender-sensitive ASM formalization strategy be implemented in sub-Saharan Africa under the auspices of the SDGs? On the one hand, and as already highlighted, the SDGs are very gender-focused, containing 'a heavy dose of pro-poor, pro-women, pro-equality, pro-development targets, which will challenge Africa' (Ighobor, 2015, p. 5). But on the other hand, whilst the SDGs focus heavily on gender, the UN and sister agencies are comparatively less explicit on how to approach challenges in regions of the world where the informal sector is sizable and deeply-rooted, such as subSaharan Africa. The ILO identifies only two 'Relevant SDG Targets related to Informal Economy', although each applies to gender. They are as follows: 1) 8.3 Promote development-oriented policies that support productive activities, decent job creation, entrepreneurship, creativity and innovation, and encourage formalization and growth of micro-, small- and medium-sized enterprises including through access to financial services; and 2) 10.2 By 2030 empower and promote the social, economic and political inclusion of all irrespective of age, sex, disability, race, ethnicity, origin, religion or economic or other status. Apart from having to devise policies and interventions capable of empowering and delivering support to women in sub-Saharan Africa and reaching the informal 'spaces' where they mostly work, there is the added challenge of tailoring these to ASM, which itself is a neglected sector. The challenge promises to be enormous, requiring a refining of interventions in line with the dynamics of the region's informal ASM 'spaces' and the needs of the specific groups of individuals who populate them. In this particular case, a starting point would seem to be a more nuanced understanding of the region's informal economy itself, and the roles and trajectories of the women working here, which this section of the paper provides.

The economic growth sub-Saharan Africa has experienced in recent years has been steady and impressive (Figure 1). The changes it has spawned, however, have failed to create jobs, largely because they have been linked to developments made in the large-scale mining, and oil and gas sectors, both of which are capital-intensive and where, consequently, employment opportunities are scarce. The situation was markedly different prior to the extensive liberalization carried out under the auspices of structural adjustment, a time when import-competing capital-intensive industries typically operated in the formal (private and public) sector (Verick, 2006). But under import liberalization, businesses across sub-Saharan Africa have been forced to reduce labour costs, through layoffs and cutting of workers' benefits, just to remain competitive, and most eventually succumbed to international competition (UNECA, 2004). The region has, consequently, become dependent on revenue from exports of fuel and mineral resources (Table 1) and over-reliant on imported finished goods. This seems to be the pattern Africa-wide: recent data show that 51 percent of the continent's exports are unprocessed raw materials (versus 12 percent of its imports) whilst 63 percent of its imports are fully-processed (versus 20 percent of its exports), making it a net importer of manufactured goods. Even if sub-Saharan Africa was committed to reversing this trend and did become a popular destination for manufacturing, it is unlikely that it would be able to absorb most of its university graduates: whilst regional spending on education during the period 2000-2013 was 16.3 percent of government expenditure, more than the global average of 14.1 percent, only 7 percent of its students in higher education enrol in science, technology, engineering and mathematics (OECD, 2018), the skills in greatest demand in the sector. Africa 'in general', Gelb et al. (2017) explain 'does 
not appear to be posed to embark on a manufacturing-led takeoff, stepping into the shoes of emerging Asia' (p. 28).

An inevitable consequence of growth with so few - what the OECD (OECD, 2018) refers to as - 'quality jobs' is hardship and poverty. According to data compiled by the International Labour Office (ILO), in sub-Saharan Africa, extreme poverty (those living on less than US\$1.90/day) has dropped since 2000 but is still exceptionally high at 36.6 percent, as is moderate working poverty (those living on US\$1.90US\$3.10/day) at 24.4 percent (ILO, 2018). This explains why most of the region's population turn to a buoyant informal economy, including activities such as ASM, for their incomes. It is challenging, with such limited information available, to determine, with accuracy, the precise number of people who today, work in the informal economy in sub-Saharan Africa. But the broad consensus is that it accounts for 30-90 percent of the region's total non-agricultural employment and 25-65 percent of its GDP (IMF, 2017): at the one extreme is South Africa, where the figure is an estimated 34 percent, whilst at the other extreme are locations such as Benin, where it is approximately 91 percent.

Figure 1: Real GDP growth in sub-Saharan Africa, 2006-Present ${ }^{4}$

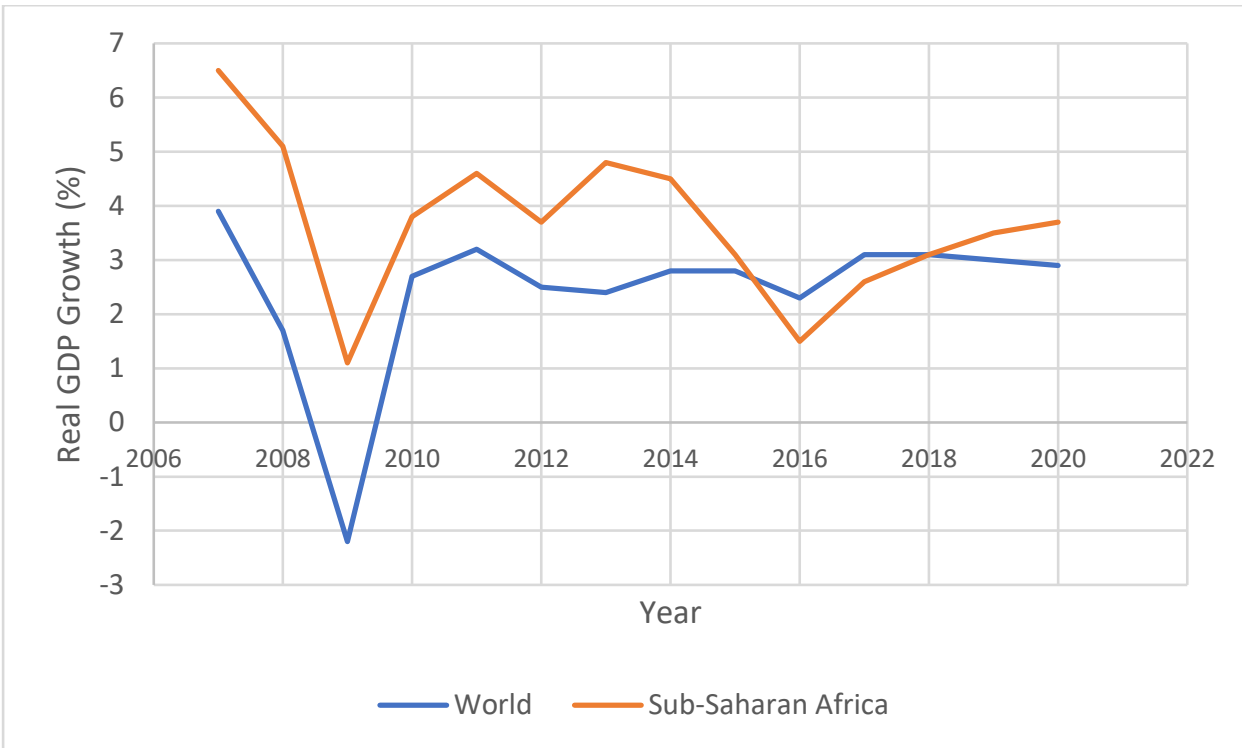

Sources: World Bank, 2010, 2014, 2016, 2018

\footnotetext{
${ }^{4}$ The data for 2017-2020 are estimates.
} 
Table 1: Natural Resource dependency in selected countries in sub-Saharan Africa

\begin{tabular}{|c|c|c|}
\hline Country & Commodity & \begin{tabular}{|l|} 
Commodity \\
Export \\
Dependence \\
(percent) \\
\end{tabular} \\
\hline Angola & Oil & 99 \\
\hline Botswana & Diamonds & 97 \\
\hline Burkina Faso & $\begin{array}{l}\text { Ores, metals, non-monetary gold and } \\
\text { precious stones }\end{array}$ & 44 \\
\hline Cameroon & Oil & 58 \\
\hline $\begin{array}{l}\text { Central African } \\
\text { Republic }\end{array}$ & $\begin{array}{l}\text { Ores, metals, non-monetary gold and } \\
\text { precious stones }\end{array}$ & 50 \\
\hline Chad & Oil & 94 \\
\hline $\begin{array}{l}\text { Congo } \\
\text { Brazzaville }\end{array}$ & Oil & 92 \\
\hline DR Congo & $\begin{array}{l}\begin{array}{l}\text { Ores, metals, non-monetary gold and } \\
\text { precious stones }\end{array} \\
\end{array}$ & 83 \\
\hline $\begin{array}{l}\text { Equatorial } \\
\text { Guinea }\end{array}$ & Oil & 99 \\
\hline Gabon & Oil & 82 \\
\hline Ghana & $\begin{array}{l}\text { Oil and ores, metals, non-monetary gold and } \\
\text { precious stones }\end{array}$ & 54 \\
\hline Liberia & $\begin{array}{l}\text { Fuels, and ores, metals, non-monetary gold } \\
\text { and precious stones }\end{array}$ & 52 \\
\hline Mali & $\begin{array}{l}\text { Ores, metals, non-monetary gold and } \\
\text { precious stones }\end{array}$ & 51 \\
\hline Niger & $\begin{array}{l}\text { Oil, and ores, metals, non-monetary gold and } \\
\text { precious stones }\end{array}$ & 81 \\
\hline Nigeria & Oil and gas & 95 \\
\hline Sierra Leone & $\begin{array}{l}\text { Ores, metals, non-monetary gold and } \\
\text { precious stones }\end{array}$ & 94 \\
\hline
\end{tabular}

Sources: UNCTAD, 2015; UNDP, 2015

The informal 'spaces' found in sub-Saharan Africa today are dynamic and bustling with entrepreneurial activity; its ASM sector is no exception. Early accounts of the region's informal activity (e.g. De Lattre, 1990; Osirim, 1993; KAbadaki, 1994), however, focused overwhelmingly on the struggles endured by aspiring entrepreneurs: their restrictive work environments; how they struggle to earn profits, except in cases where there are significant subsidies; and how there are numerous bottlenecks that must be overcome in order for activities to expand. This body of work, Elken (1988) observed at the time, 'makes gloomy reading' (p. 171). The narrative about entrepreneurship in sub-Saharan Africa has changed over the years but it remains overwhelmingly negative, focusing, more recently, on how the region is 'losing GDP' from the sector and/or how its operators are avoiding paying tax (e.g. Dube and Casale, 2016; Danquah and Osei-Assibey, 2018). Some scholars (e.g. Spring and McDade, 1998) have shared valuable insights beyond this, drawing attention to the dynamics of the entrepreneurship proliferating in the informal economy in sub-Saharan Africa and its economic importance at the 
community level. But the bulk of analysis put forward on the subject fails to take stock of circumstances which give rise to informal activities in the first place.

It has mostly been the donor organizations - many of which, ironically, have ushered in the investment frameworks and catalyzed the industrial activity and growth responsible for creating the burgeoning informal economy now rooted in sub-Saharan Africa - that have kept the dialogue focused on the experiences of individuals. Most of the economic activity that proliferates in the region's informal sector is akin to what is often referred to in the literature as 'necessity entrepreneurship', or activity pursued by individuals due to 'poverty and lack of employment opportunities', for whom 'Starting a business is not their prime consideration until they have exhausted other options' and which overall, 'In order to survive over poverty and/or unemployment, they are forced to be entrepreneurs' (Cheung, 2014, p. 2). Experiences from sub-Saharan Africa did not directly inform the pioneering analysis that emerged on necessity entrepreneurship during the 1980s. But efforts have been made, retrospectively, to unpack the idea in an attempt to broaden understanding of the complexities of the eclectic collection of entrepreneurial activities that have proliferated in the region's burgeoning informal economy.

Particular attention has been paid to articulating how the growth of most are linked to hardship, a hallmark of necessity entrepreneurship. Officials at the African Development Bank, for example, stress the importance of 'Recognizing Africa's Informal Sector', the expansion of which 'is often associated with increasing poverty and weak employment conditions', due in large part to how 'many African countries have experienced a growth revival, but this has not necessarily generated decent jobs'. ${ }^{5}$ In sub-Saharan Africa, therefore, the informal sector, in effect, 'acts as a safety net, providing employment and income to a large and growing working-age population that may otherwise be unemployed in the absence of sufficient opportunities in the formal sector' (IMF, 2017, p. x). The reliability of this employment, however, is a concern: according to the ILO (ILO, 2018), sub-Saharan Africa has the highest 'vulnerable employment rate' in the world at 72 percent. With self-employment accounting for an estimated 70 percent of all work in sub-Saharan Africa (ILO, 2009), it is unclear how, in line with recommendations put forward by the African Development Report 2011 (African Development Bank, 2011), the region can possibly produce more 'opportunity-driven entrepreneurs' - individuals who are consciously looking to take advantage of business opportunities (Stoner and Fry, 1982; Bhave, 1994) - or be expected to put individuals leading precarious existences in a position 'to innovate in order to take full advantage of market opportunities' (p. 122) on their own.

Whilst information may be limited, there are enough data and anecdotes in the literature to conclude that the 'vulnerable employment rate' in sub-Saharan Africa is highest amongst women. This is largely because today, for women across the region, informal employment is 'pervasive' (ILO, 2018, p. 10), as fewer than 23 percent fall into the category of 'wage and salaried workers' (ILO, 2017). The ILO (ILO, 2009) provides a glimpse of the precarious existences led by many of these women:

[in sub-Saharan Africa,] within the informal economy, women are concentrated in the lower end where decent work deficits are the greatest. Outside of agriculture, women are in the least protected and most precarious forms of work, including as domestic workers, unpaid contributing family workers and industrial outworkers. Those in this last category have some of the lowest average earnings of all, since they often lack firm contracts, they may not be paid for months and they are made responsible for non-wage costs of production. [p. 32]

\footnotetext{
5 'AFDB: Championing Inclusive Growth Across Africa', www.afdb.org/en/blogs/afdb-championing-inclusivegrowth-across-africa/post/recognizing-africas-informal-sector-11645/ (Accessed 13 April 2018).
} 
Chen (2008) has pulled together some illustrative examples, including Ghana, where 'own-account workers and unpaid contributing family workers' accounted for 77 percent and 47 percent of women's non-agricultural employment, respectively (p. 4). Similar patterns were identified much earlier in Benin, Chad and Mali, where, at the turn of the century, over 95 percent of individuals working in the nonfarm informal sector were reportedly women (Chen, 2001). Most of these individuals and women elsewhere in sub-Saharan Africa, however, are not only working informally but are self-employed, undertaking work as individuals or family heads that would fall into the category of necessity entrepreneurship (Table 2).

If, in the words of the African Development Report 2011, they are 'to innovate in order to take full advantage of market opportunities', they must overcome a series of barriers preventing their advancement and growth as entrepreneurs in sub-Saharan Africa. The report itself identifies many of these, echoing ideas that have been communicated widely over the past four decades (see e.g. UNECA, 1988; Spring and McDade, 1998). It furthermore draws attention to findings from surveys of 28 countries in sub-Saharan Africa conducted by researchers at the World Bank which reveal that in all, with the exception of Botswana, there are unequal rules for men and women in at least one of the following areas: taxation, employment, property use and access to institutions. These unequal rules extend to the region's informal employment, where the gender gap often exceeds 20 percent, exacerbated heavily by sharp disparities in education between the male and female populations (Dieterich et al., 2016).

This paper focuses on the women who work informality in ASM camps in sub-Saharan Africa. The sector's activities are mostly found scattered across throughout the region's rural patches, the significance of which Hallward-Driemeier and Hasan (2013) underscore:

With two-thirds of the region's [sub-Saharan Africa's] population in rural areas, land rights are thus critical in determining income opportunities in Sub-Saharan Africa. Women's rights to their assets and income are central to their ability and incentive to operate and expand their businesses. As many people work in rural areas and informally, customary law and traditional forms of justice, rather than the formal legal system, may be more relevant. [p. 26]

Dieterich et al. (2016) summarizes the trajectory women find themselves on in the informal economy in rural sub-Saharan Africa. Within the region's low-income countries, explain the authors, agriculture engages over 50 percent of the labour force, and whilst participation of females exceeds that of men, a lack of land ownership, credit and finance, and other production inputs often limits productivity and leaves them in a poverty-stricken state. As living standards improve, an increasing number of individuals move out of agriculture and into waged positions and the household enterprise sector. But females, including those who are married, tend to find it difficult to make either transition because of the abovementioned barriers.

Whilst data and case study analysis are in short supply, when what limited information that is available is grafted on to this trajectory, the picture emerging for women engaged, informally, in ASM is strikingly similar. But even if this were to be entirely accurate, as the section that follows explains, policymakers and donors simply do not have enough data and testimonials on-hand to make important and effective decisions about women engaged in ASM in sub-Saharan Africa. The fates of these women are - for better or for worse - determined heavily by ASM's policy treatment, and individual governments' commitment to formalize and support the sector's activities. 
Table 2: Percentage of self-employed persons in selected countries in sub-Saharan Africa

\begin{tabular}{|c|c|c|c|c|}
\hline & 2015 & $2005-2014$ & 2009 & 2009 \\
\hline Country & Population & $\begin{array}{r}\text { People living } \\
\text { below the } \\
\text { poverty line }\end{array}$ & $\begin{array}{r}\text { Self-employed in } \\
\text { nonfarm employment }\end{array}$ & $\begin{array}{r}\text { Women's share in } \\
\text { nonfarm self- } \\
\text { employment }\end{array}$ \\
\hline & (Millions) & (\%) & (\%) & (\%) \\
\hline Benin & 10.9 & 36.2 & 88.7 & 59.9 \\
\hline Botswana & 2.3 & 7.4 & 18.8 & 44.7 \\
\hline Burkina Faso & 18.1 & 40.1 & 69.7 & 53.6 \\
\hline Burundi & 11.2 & 64.6 & 35.6 & 22.0 \\
\hline Cameroon & 23.3 & 37.5 & 43.8 & 23.1 \\
\hline Central African Republic & 4.9 & 62.0 & 57.5 & 47.4 \\
\hline Chad & 14.0 & 46.7 & 72.4 & 54.0 \\
\hline Comoros & 0.8 & 44.8 & 61.0 & 24.8 \\
\hline Congo, Dem. Rep. & 77.3 & 63.6 & 51.8 & 39.5 \\
\hline Congo, Rep. & 4.6 & 46.5 & 38.7 & 42.6 \\
\hline Ethiopia & 99.4 & 29.6 & 73.6 & 60.9 \\
\hline Ghana & 27.4 & 24.2 & 66.9 & 74.6 \\
\hline Guinea & 12.6 & 55.2 & 71.8 & 31.0 \\
\hline Guinea-Bissau & 1.8 & 69.3 & 48.4 & 35.5 \\
\hline Kenya & 46.1 & 45.9 & 61.0 & 67.6 \\
\hline Lesotho & 2.1 & 57.1 & 17.6 & 56.4 \\
\hline Liberia & 4.5 & 63.8 & 40.8 & 38.7 \\
\hline Madagascar & 24.2 & 75.3 & 46.3 & 45.9 \\
\hline Malawi & 17.2 & 50.7 & 33.2 & 24.5 \\
\hline Mali & 17.6 & 43.6 & 83.9 & 57.2 \\
\hline Mozambique & 28.0 & 54.7 & 46.5 & 29.2 \\
\hline Niger & 19.9 & 48.9 & 83.7 & 47.4 \\
\hline Rwanda & 11.6 & 44.9 & 25.4 & 21.9 \\
\hline South Africa & 54.5 & 53.8 & 11.6 & 57.1 \\
\hline Sudan & 40.2 & 46.5 & 40.7 & 12.5 \\
\hline Tanzania & 53.5 & 28.2 & 27.5 & 18.8 \\
\hline Togo & 7.3 & 55.1 & 68.3 & 61.0 \\
\hline Zambia & 16.2 & 60.5 & 17.9 & 46.6 \\
\hline
\end{tabular}

Sources: Adams et al., 2013; UNDP 2017

\section{Informal Artisanal and Small-Scale Mining in Sub-Saharan Africa: 'Spaces' of Exploitation or Economic Opportunity for Women?}

The question posed above cannot be answered with the quantity of information available. Accounts of women's experiences in ASM can be found scattered across the literature but significantly, few connect with the policy context, in particular how the governance of the informal 'spaces' in which the activities they engage shapes their livelihoods. A big part of this exercise, therefore, is 
understanding why and how informal ASM activities proliferate across rural and peri-urban subSaharan Africa, a problem which the architects of the AMV must ultimately unravel if they are committed to reaching and capacitating women employed in the sector. After pulling together the material published on women in ASM, in the process underscoring how little is known about, and the need for more research on, this subject, this section of the paper provides explanations for why, throughout the region, the sector's activities occur mostly in informal 'spaces'. It concludes by asking whether the region's governments, guided by the AMV and SGGs, are in a position to implement propoor formalization programs for ASM, let alone implement schemes tailored to the needs of the specific groups who populate the sector's informal 'spaces', in this case, women.

\subsection{Surveying the Literature}

Women's participation in ASM is a subject that has not been entirely overlooked; discussion began to surface in the 1990s. One of the earliest and most critical pieces was produced by Labonne (1996), who stressed the importance of 'Acknowledging the women themselves', and prescribed a series of steps which - presumably intended for policymakers - should take to make this happen. At about the same time, the United Nations produced a comprehensive report on the ASM sector (UN, 1996), which states that 'Women constitute a significant portion of the human resources in small-scale mining and artisanal mining, and in some areas, they are the predominant participants'. The report further acknowledges the diverse roles played by women at ASM sites, including taking 'part as concession owners, hawkers and providers of services and goods, labourers, dealers and buying agents, food preparers, and equipment owners, who hire out items such as shovels and pans' (p. 221). Other reports (e.g. Davidson, 1993; Traore, 1994; Burke, 1997) highlight similar points about women in ASM, many of which are relevant to sub-Saharan Africa.

This body of research, however, failed to have an impact in the policymaking and donor space at the time because the recommendations were being made in a vacuum. Organizations such as the World Bank, the United Nations Department for Economic and Social Affairs, the Intermediate Technology and Development Group and GTZ were financing promising technical, policy and geological work for ASM in the 1990s. But most of it was siloed, disconnected from broader development policies and dialogues at the time, including those linked to Agenda 21 and, in the case of sub-Saharan Africa, rural economic development programs being implemented by influential regional agencies such as the African Development Bank and the United Nations Economic Commission for Africa. Overall, regional development policy machinery failed to view and ultimately treat ASM as an embedded part of rural African societies, despite explicit reference to its activities being connected to sectors such as agriculture (see e.g. Wels, 1982; Kumar and Amaratunga, 1994; Maconachie and Binns, 2007). Most of these interventions, to paraphrase ILO officials commenting on the ineffectiveness of the support structures in place for the sector at the time (ILO, 1999), therefore, inevitably 'gently wound down' once funding dried up. This is the challenge which signatories to the AMV face today: devising ASM formalization schemes which can be nestled within comprehensive policy frameworks, the design of which has been informed by the SDGs.

Failure to cement ASM in the mainstream development literature in the 1990s and early-2000s are a main reason why the struggles and experiences of the sector's female participants have gone virtually overlooked, despite being a time when gender in sub-Saharan Africa and the experiences of the region's women entrepreneurs were attracting considerable attention in the academic community (e.g. Ahwireng-Obeng, 1993; Pickering et al., 1996; Chitsike, 2000). It seemed to be a case of the work mentioned above being published mostly in policy and trade journals which had minimal readership among scholars in African studies and international development; and, failure on the part of their authors to 'speak' to broader development challenges, in this case, those concerning gender and women's empowerment. It was not until Hinton et al. (2003) that a detailed, engaging and up-to- 
date survey of women's participation in ASM was produced. Reflecting on the general lack of input on the subject at the time, the authors reinforced the first recommendation put forward by Labonne (1996) on the importance of 'gathering data on female participation in mining and a comparison of their roles', data collection which, the author argued, 'should be undertaken on a participatory basis and should involve operators in the sector, district mining staff, local government officials and others involved in artisanal mining' (p. 121). Building on this point, Hinton et al. (2003) concluded, based on the information they harvested and presented, that 'The paucity of reliable information concerning women's involvement in artisanal mining represents a major knowledge gap', and that 'In most reports on artisanal mining, a discussion of a women's role is altogether absent, or is grouped together with child labour, often in the same paragraph' (p. 182). Very little work, however, has since been undertaken which would qualify as comprehensive responses to this call to address the 'paucity of reliable information'. One of the more telling signs of the lack of activity taken on this front is the repeated quoting of the same data. It begins with the 40-50 percent figure typically highlighted in reports as the share of women engaged in ASM worldwide. Over two decades ago, Labonne (1996) claimed that 'Close to half of the 6 million artisanal miners are women' (p. 119), a figure which Hinton et al. (2003) suggested was closer to 30 percent. This may have been the case, given the data that had emerged from the ILO office a few years previously, drawn from censuses and questionnaires distributed globally. The information gathered (see ILO, 1999) suggested that women's employment in ASM globally ranged from 5 percent in Malaysia to 50 percent in Tanzania. The 30 percent figure, however, still continues to be cited in research briefs (see e.g. Malpeli and Chirico, 2013; Olayide et al., 2013; Chichester et al., 2017), despite claims made in the World Bank's Gender Dimensions of Artisanal and Small-Scale Mining A Rapid Assessment Toolkit (Eftimie et al., 2012) that 'their [women's] involvement may now be much higher' (p. 6) and no additional census work having been conducted to justify this figure's continued use. The absence of a reliable baseline and accompanying country-level disaggregated population data for ASM makes it challenging to design interventions aimed at supporting women engaged in the sector and to source the finance required to support them.

The situation is even more contentious in the case of sub-Saharan Africa. Here, the figure which continues to be quoted as the proportion of the ASM workforce being women is 40-50 percent, despite there being little clarification in the literature about how this was arrived at, although it is likely that Hinton et al. (2003) developed this figure using, once again, country-level estimates provided by the ILO (ILO, 1999). What is surprising, however, is that despite the rapid growth the sector has since experienced throughout the region, research documents (Scott, 2014; Buss et al., 2017; Weldegiorgis et al., 2018) continue to quote this figure, which would imply that the composition of the sector's workforce has not changed. But what has perhaps been even more disconcerting is the haste with which donors have accepted this 40-50 percent figure and quoted it in their reports (Ruzvidzo, 2015; WHO, 2016), seemingly without scrutinizing the validity or sources of the data used to compute it. Table 1 presents the country figures typically quoted in gender-focused work on ASM in sub-Saharan Africa, many of which have been cited for more than two decades.

Table 1: Estimated number of female ASM operators in selected countries in sub-Saharan Africa

\begin{tabular}{|l|l|l|}
\hline Country & $\begin{array}{l}\text { Estimated number of ASM } \\
\text { operators }\end{array}$ & $\begin{array}{l}\text { Estimated Percentage of Women } \\
\text { in ASM }\end{array}$ \\
\hline Malawi & 40,000 & $10 \%$ \\
\hline Mozambique & 60,000 & $30 \%$ \\
\hline Tanzania & 550,000 & $25 \%$ \\
\hline South Africa & 10,000 & $5 \%$ \\
\hline Zambia & 30,000 & $30 \%$ \\
\hline Zimbabwe & 350,000 & $>50 \%$ \\
\hline Ghana & $200,000^{* *}$ & $50-75 \% *$ \\
\hline
\end{tabular}

Sources: Dreschler, 2001; Hentschel et al., 2002 
It has long been argued that many women in the region 'work extensively along with children and other family members in artisanal and small-scale mining in communities where it takes place', carrying out tasks which 'can be a demanding, dangerous, and often only marginally profitable sector for women, and job opportunities in ASM, even more than larger scale mining, can increase women's burden of working both outside and inside the home' (Eftimie et al., 2009, p. 23). The implication here is that these women are confined to work that is 'dangerous', 'demanding' and/or 'marginally profitable', although this is typical of the types of income-earning activities available in most informal 'spaces'.

These are the messages which have resonated powerfully in the work published on the subject in recent years. Despite also, at times, drawing on obsolete demographic data, many authors have offered detailed descriptions of the roles women play at selected ASM sites in the region, and the challenges they face on a daily basis. The work published on DR Congo has been the most detailed, focusing primarily on the abuse women engaged in ASM and/or who reside close to sites controlled by the police and local politicians are subjected to, as well as how these dynamics influence individuals' decisions to migrate to sites in search of work (see e.g. Bashwira et al., 2014; Rustad et al., 2016; Maclin et al., 2017). Most of the remaining studies focus on women's experiences with accumulating incomes in the ASM sector. Werthmann (2009) offers a particularly optimistic glimpse of informal gold mining camps in Burkina Faso. Here, migrating women recognize that their movement into goldproducing communities puts them in a position to pursue a range of income-earning activities and in the process, accumulate significant wealth. In neighbouring Ghana, Yakovleva (2007) reported similar findings from interviews with female miners operating illegally in the country's Eastern Region. Here, it was reported by interviewees that the major motivation for women to engage in informal mining activity was a lack of productive employment. Specifically, a shortage of land, underdeveloped local markets, an inability to physically access wider markets and a lack of financial credit push the poorer women inhabiting rural areas to enter low-skilled, less productive jobs in illegal small-scale mining. Findings reported by Armah et al. (2016) build on these findings, suggesting that, in Ghana, 'disparities exist in the important factors that contribute to discrimination in working conditions of the male and female artisanal and small-scale goldminers' (p. 473). The authors determined from cross-sectional survey of 482 male and 106 female artisanal and small-scale gold miners in the country that overall, age and years of experience were relevant for the former, whilst education and number of years lived in the community proved important for the latter. These findings complement those in Buss et al. (2017), who, drawing on feedback from interviews conducted in Rwanda, Uganda and DR Congo, report that women at ASM sites are compensated less than men, and face significant barriers in their efforts to access the credit and technologies needed to increase their earnings.

Once again, can an AMV, implemented under the auspices of the SDGs, facilitate the design and implementation of formalization and support programs for ASM that are capable of reaching and improving the livelihoods of these women? There are two issues to consider beforehand, the first being a holistic understanding of the circumstances which have driven these women to mine in the first place. Their migration and decision to pursue work in ASM is linked to personal hardship, which is itself at the heart of the 'poverty-driven' narrative that again, has dominated debates on the sector's growth, particularly in sub-Saharan Africa, for more than three decades (Barry, 1996; ILO, 1999; UNECA, 2003; Hilson, 2009). Revisiting points raised at the outset of this paper, this narrative is premised upon the idea that 'Informal mining is decisively linked to rural stagnation and poverty' and is 'the livelihood that provides an alternative to or supplementing traditional livelihoods' (Lahiri-Dutt, 2015, p. 529). The women interviewed by both Yakovleva (2007) and Werthmann (2009) were illustrative examples of this: poor individuals who were driven to mine because of the need to alleviate their hardships. Similarly, in the case of Buss et al. (2017), there were reports of women feeling compelled to mine also because of hardship, induced by factors ranging from husbands no longer giving them money to a lack of opportunity in their hometowns. 
In these, and related, cases, the state of the agricultural sector has governed heavily women's movement into ASM and has shaped their livelihood strategies. Once again revisiting points raised earlier, there is a burgeoning body of literature which highlights the links between subsistence farming and ASM in sub-Saharan Africa (see e.g. Maconachie and Binns, 2007; Pijpers, 2011; Kamlongera, 2011), highlighting, in particular, how diminished financial returns from the former has triggered movement into the latter. Most of the women profiled in each of the studies cited above have farming backgrounds and remain connected with agriculture in some capacity. For example, Yakovleva (2007) reports that 'It is evident that families re-orient their usual subsistence farming existence towards galamsey [i.e. informal gold mining] activities, but also retain their small farms, which often increases women's workloads' (p. 37), phenomena that mirror findings shared in other studies (e.g. Banchirigah, 2008; Hilson and Garforth, 2013) which draw attention to the inseparable links between subsistence agriculture and ASM in Ghana. Buss et al. (2017) share similar stories from their research in Central and East Africa which detail women's ties with agriculture, specifically individuals who reported using earnings to purchase farm plots and domestic animals. At the other extreme is the Eastern DR Congo (see e.g. Geenen, 2014; Kelly et al., 2014), where protracted conflict, 'through looting, destruction of property, and mass displacement, has led to the deterioration of the agricultural industry and markets', in turn leading 'many to rely solely on ASM for their livelihoods' (Maclin et al., 2017, p. 117). Before the war, Bashirwa et al. (2014) explain, the large majority of the rural population in North and South Kivu derived their income from agriculture and livestock rearing. But today, unsafe roads, deteriorating infrastructure, the insecurity of land tenure and a shortage of fertilizers have crippled even the most committed of Congolese who have attempted to re-enter their lives as full-time farmers (Kelly et al., 2014). It also explains why so many vulnerable people in the country, including women, take such great risks to pursue work at ASM sites.

These experiences underscore why, when assessing the dynamics of ASM in sub-Saharan Africa, 'transcending' the poverty narrative and discussions on how changes in agriculture have fuelled the sector's growth, as Verbrugge (2016) suggests must happen, would be difficult, if not, impossible. The evidence in support of individual hardship and diminished income-earning opportunities from agriculture fuelling the growth of ASM across the region is overwhelming; ignoring either would be to deny the very forces that have shaped - and which continue to shape - the livelihoods of those engaged in ASM, in this case, women. When the experiences of the women in question here, with their farming backgrounds, are mapped on to the rural work trajectory which Dieterich et al, (2016) describes, the barriers preventing their movement out of agriculture into waged positions and the household enterprise sector, including their progression in informal ASM 'spaces', become more visible. It was Dreschler (2001) who first broached this issue, taking stock of the movements, in the 1990 s, of rural African populations out of agriculture into ASM and subsequently weighing in on what implications this had for women. Drawing on experiences from Southern Africa, the author argued that women's maneoverability in the sector, including their ability to ascend to the top of the labour hierarchy and become concession holders, was being held back by their family responsibilities, cultural beliefs and a lack of education:

Most of the women [in ASM] are found at the very bottom end of the sector's hierarchy, doing subordinate work...Women are also not that flexible and able to move around in the country. So, while men are often following the gold-rush in remote corners of the region, women are usually tied to their households and involved in seasonal panning activities around their home areas...Small-scale miners are generally men. Although some women take part in transporting and washing the ore, their other roles (mother, housewife, caretaker) still predominate. Many cultural barriers hinder women's involvement in artisanal mining. In some parts (for example, in N'tulo) Niassa women are not allowed to work at the mine site because they attract bad spirits. Here women are only allowed to sell food and beer. In Manica women Small-scale 
Mining and Sustainable Development within the SADC Region 59 are not allowed to dig trenches, but they can transport the ore to the processing sites and wash it...[p. 7, 58-59]

The points raised by the author which more recent analysis has reinforced is that the activities women are often confined to in informal ASM 'spaces' across sub-Saharan Africa are largely a reflection of their cultural status and level of education, and/or are an extension of what they carry out in the household. In the case of Ghana, Yakovleva (2007) surmised from findings that the role played by women within families as a carer for children is transferred to galamsey [unlicensed artisanal mine] sites'. The author furthermore concluded that 'Due to their low educational levels, household responsibilities, low technical knowledge and restricted employment mobility, women enter illegal small-scale mining "unskilled" and therefore are afforded few opportunities to gain productive employment', which is why 'female galamsey workers have little chance of participating in more lucrative areas of the industry such as trade, management and equipment handling' (p. 38). Similarly, Buss et al. (2017) argue, based on their findings from research conducted in Eastern Africa, that 'The work possibilities at ASM zones for women were also strongly shaped by pressures on them by their families, households and the wider community concerning their gendered duties', and that 'It is clear that for many women, their participation in artisanal mining is shaped by a combination of productive and reproductive roles' (p. 34-35).

This leads to the second issue and ultimately, the main challenge with supporting women engaged in ASM in sub-Saharan Africa: determining what constitutes 'better' in this context. On the one hand, throughout sub-Saharan Africa, women are taking enormous risks to engage in ASM and once involved, expose themselves to even more dangers. There are countless accounts in the literature of sexual violence, physical abuse and other forms of discrimination against these women (see e.g. ITUC, 2011; Mbambi and Kandolo, 2016). But on the other hand, whilst struggling mightily and earning much less compared to their male counterparts, many African women who are engaged in ASM believe the risk to be worthwhile. From her research conducted in Ghana, Yakovleva concluded that women would prefer engaging in less arduous work at sites and struggle to accumulate the savings from their work to invest in other ventures but choose to pursue employment in ASM because it yields higher income than other activities and enables them to cope with economic pressures in the household. In the case of the Central and East Africa work, Buss et al. (2017) report that, whilst a sizable share of women interviewed had no education, how patriarchal norms and beliefs prevent their full participation in ASM activities, and that all earn considerably less than their male counterparts, collectively, they are all benefitting enormously economically from this work. Based on feedback from interviews conducted in Uganda, for example, women generate roughly half the income of males but still earn three times more from mining than any other income-earning activity. Findings such as this are significant, as close to 60 percent of women surveyed in Uganda, Rwanda and DR Congo claimed to be the main earner for their families. But these are hardly examples of what Verbrugge would possibly consider to be how 'ASM-expansion creates opportunities for a heterogeneous group of actors that are able to capitalize on the increased and more diverse demands of the mining community' (p. 109). They are rather cases of people driven by poverty - in this case, women - who, in the absence of viable income-earning opportunities, take enormous risks to generate incomes. In many countries in the region, several individuals, recognizing the economic importance of this work and inability of women to abandon it but also, the risks involved carrying it out, have established representative organizations in a bid to strengthen the female voice in the sector (see Table 2). 
Table 3: Selected women miners associations in sub-Saharan Africa

\begin{tabular}{|c|c|c|c|}
\hline Country & Name & Year Established & Description \\
\hline Mali & $\begin{array}{l}\text { Association des } \\
\text { femmes minieres } \\
\text { du Mali (AFEMINE) }\end{array}$ & 2002 & $\begin{array}{l}\text { Brought together the operational structures and groups of active women working in the mining sector in } \\
\text { Mali. It has trained and supported women who work in the mining sector, their central objective being to } \\
\text { facilitate the growth of artisanal activities from the individual/family level into cooperatives. }\end{array}$ \\
\hline Malawi & $\begin{array}{l}\text { Malawi Women in } \\
\text { Mining Association } \\
\text { (MAWIMA) }\end{array}$ & 2000 & $\begin{array}{l}\text { has and acts as a direct link to the local government as well as government departments such as the } \\
\text { Department of Mines and the Geological Survey Department, all under Ministry of Natural Resources Energy } \\
\text { and Mining...It is representative and most of the members were involved in the drafting of the latest mining } \\
\text { law and policy as well as the Artisanal and Small Scale Mining Policy." }\end{array}$ \\
\hline Ghana & $\begin{array}{l}\text { Women in Mining } \\
\text { Ghana }\end{array}$ & 2000 & $\begin{array}{l}\text { Women in Mining (WIM) Ghana, was incorporated as a company limited by guarantee in the year 2015. The } \\
\text { main purpose among others is to serve as an advocacy body for all women working in the mining sector } \\
\text { (Industry, Academia and Government) by offering training, mentorship, networking and research projects. } \\
\text { Thus, WIM incorporates women from upstream to downstream (i.e. whole value chain) in the resources } \\
\text { sector. }\end{array}$ \\
\hline Tanzania & $\begin{array}{l}\text { Tanzania Women } \\
\text { Miners Association } \\
\text { (TAWOMA) }\end{array}$ & 1997 & $\begin{array}{l}\text { Has an executive and management committee and representatives who participate in various trade fairs } \\
\text { and workshops. The organization's management has lobbied (and facilitated) change in the country's mine } \\
\text { licensing system, which has affected small-scale operators. Its staff have run workshops, training miners in } \\
\text { a number of areas, including health and safety, the environment and business management. }\end{array}$ \\
\hline Zambia & $\begin{array}{l}\text { Association of } \\
\text { Zambian Women in } \\
\text { Mining (AZWIM) }\end{array}$ & 1997 & $\begin{array}{l}\text { The association aims to represent women involved in mining of diverse minerals across Zambia (e.g. } \\
\text { amethyst in the Southern Province; tourmaline and red-garnet in the eastern province; industrial } \\
\text { minerals). It is affiliated to organisations both locally and internationally. External groups include } \\
\text { 'International Women in Mining' (IWIM). There was a splinter group that emerged from AZWIM and } \\
\text { even received support under the European Union's Mining Sector Diversification Programme (MSDP). } \\
\text { But this group is less known. }\end{array}$ \\
\hline
\end{tabular}

Sources: Bathé, 2016; Rickard et al., 2017; 'Women in Mining Ghana', www.wimghana.org/about-us/who-we-are (Accessed 4 July 2018); 'TAWOMA -

Tanzania Women Miners Association', http://tawoma.blogspot.com/ (Accessed 5 July 2018). 
The designers of any empowerment and capacitation exercise which attempts to connect with women employed in the region's informal ASM 'spaces' must be able to distinguish between the positives and negatives of this work, and, very importantly, understand the details of the circumstances driving them to the sector in the first place. As a point of departure when launching any formalization scheme for hard-working female ASM operators in sub-Saharan Africa, therefore, designers should follow recommendations put forward by Bashirwa et al. (2014) who, based on their work in Eastern DR Congo, conclude that 'Given the lack of alternative livelihoods in the Kivus, we believe that it makes more sense to address the predicament of women in eastern DRC's artisanal mining areas by taking the latter's agency seriously and by helping them to strengthen their position in the mining sector itself' (p. 114). With the SDGs falling short in connecting with the nuances of the informal sector and, as will be explained, their architects failing to recognize how a sector such as ASM is a cornerstone in countless rural economies across the developing world, it seems unlikely that the AMV, which itself is very macro-level focused and being implemented from the top down, is capable of facilitating gendersensitive formalization schemes for the sector. The discussion that follows examines these issues in greater depth.

\subsection{Formalizing Artisanal and Small-Scale Mining in sub-Saharan Africa under the SDGs: Previewing the Challenge}

Much like their predecessors, the MDGs, the SDGs have attracted their share of criticism, most of which concerns their top down targets, failure to acknowledge critical grassroots-level issues and policy 'sprawl' (IISD, 2016). The problem with the MDGs, as Attaran (2005) eloquently put it, was that they were immeasurable. But this concern has also been raised about the SDGs. Winkler and Williams (2017) bring together a series of critiques which make this very point. The list includes Saiz and Donald (2017), who argued that Goal 10 ('Reduce inequality within and among countries') is not aligned with the language of the global human rights agenda; MacNaughton (2017), who also finds shortcomings with Goal 10, in particular its first target, which focuses on the bottom 40 percent of the population but does not address the gap between it and the top 10 or 1 percent; and Frey (2017), who focuses on Goal 8 ('Promote sustained, inclusive and sustainable economic growth, full and productive employment and decent work for all'), arguing that it fails to reconcile the two conflicting visions of development, namely the market-focused approach and rights-based approach, rather merging them and making the realization of the goal based on the former. The 2017 Africa Sustainable Development Report: Tracking Progress on Agenda 2063 and the Sustainable Development Goals (UNECA, 2017b) confirmed as much for sub-Saharan Africa: that 'Approximately six out of every ten SDG indicators cannot be tracked in Africa due to severe data limitations' (p. viii).

The added challenge with ASM is that the SDGs were designed without taking into careful consideration its importance in rural areas of the developing world. The problem is deeply-rooted and dates back to the UN Millennium Development Goals (MDGs), whose designers overlooked the sector to such a degree that in the most extreme of cases, farm-based livelihoods were being promoted under the auspices of the Millennium Villages project in localities such as Bonsaaso, Ghana, where the mining gold on a small scale has been the primary income-earning activity for hundreds of years (see Wilson, 2016). Failure to recognize the importance of ASM in rural development during the formative years of the Millennium Development Project could also explain why responses to calls made over the years to make the sector more visible in Poverty Reduction Papers (PRSPs) ${ }^{6}$ have been lukewarm. It is also the reason why, consequently, without guidance, in a number of African countries,

\footnotetext{
${ }^{6}$ A PRSP is a document required by the World Bank and IMF before a country can be considered for debt relief under the auspices of the Heavily Indebted Poor Countries (HIPC) initiative. It is projected as being country-led and the ideas enshrined within it arrived at via participatory processes involving a multitude of stakeholders.
} 
ASM's role has been defined very clearly in inaugural PRSPs which cover a specific period but largely forgotten about in subsequent iterations.

In an attempt to help steer the Millennium Development Project in the direction of ASM, a workshop was held at World Bank headquarters in Washington DC, 16-17 June 2005. The specific purpose of the conference, explains Hinton (2005), 'was to discuss how to raise awareness of the relevance of the artisanal and small-scale mining sector to development processes' in particular, to identify 'ways to integrate more effectively ASM issues into the wider development agenda, both through raising the profile of the sector and through mutually beneficial alignment of ASM issues with other donor priorities, including the Millennium Development Goals (MDGs), capacity building for fragile states, and conflict mitigation' (p. 9). But when the opportunities arose to address this crucial omission during the initial planning and development phases of the SDGs, the same mistakes were made, the most crucial being failure to incorporate a blueprint for ASM development in the UN's landmark document, Mapping Mining to the Sustainable Empowered lives. Resilient nations. Development Goals: An Atlas (UNDP, 2016a). It states, explicitly, that 'The scale of ASM warrants a separate guide and review to map the opportunities on how ASM can contribute to the SDGs' (p. 16). Such a sister guidance document has yet to materialize.

The onus falls on the architects of the AMV, therefore, to conceive user-friendly formalization schemes for ASM and embed them within a policy machinery in ways that speak to the SDGs. Although the AMV was designed prior to the launch of the SDGs and is, as a result, more closely aligned with the MDGs, there is considerable scope for undertaking such a task, as Winkler and Williams (2017) imply. Commenting generally, the authors explain that whilst 'the goals and targets [of the SDGs] are finalised, the indicators and monitoring frameworks are still being developed' (p. 1027). The insinuation being made by the author is that the SDGs are, indeed, broad and very macro-level in their design and orientation, and - as if conceding the limitations this causes - that specific programs must be designed if they are to be localized (see e.g. Galli et al., 2018). The publication of the UNDP's Roadmap for Localizing the SDGs: Implementation and Monitoring at Subnational Level (UNDP, 2016c), a 'roadmap aims to support local and governments and their associations to implement and monitor the SDGs and to influence national policy-making with a view to creating an enabling environment for action at local and regional level' (p. 2), signifies that even the UN's high-ranking officials recognize the need for the goals to be adapted to the local context. The generalist nature and at times, ambiguity, of the SDGs are a true testament to how, in line with the main message conveyed in the Brundtland Commission's Report, Our Common Future (WCED, 1987), that no single blueprint for sustainability exists, and consequently, the ways in which countries achieve sustainable development will ultimately vary among the different economic and political systems around the world (NRC, 1995). Acknowledging the limitations of the SDGs as an indicator framework, officials at the United Nations Economic Commission for Africa highlight what information, in the case of subSaharan Africa, is needed in order to operationalize locally, a list that includes 'Disaggregated data by age, gender, income and geographical location is necessary to better target support to groups at risk of being left behind in the development process' (UNECA, 2017b, p. viii).

Given these shortcomings of the SDG framework, including its limited ability to speak to the needs of informal economies, is the AMV capable, on its own of facilitating the design of policies in tune with the dynamics of ASM. Moreover, is it the correct blueprint for engineering the localization of accompanying programs in signatory countries which, in line with its objective of Boosting Artisanal and Small-Scale Mining, empowers and supports women engaged in sector? Formalization, a number of scholars have argued over the years (see e.g. Van Bockstael, 2014; Hilson and Maconachie, 2017, Hilson et al., 2017), helps to establishe the platform donors and host African governments need to target specific individuals engaged in ASM - in this case, women - to equip them with licenses and support them. It seems to be at the heart of the AMV dialogue on ASM - though at times, implicitly - 
and as UN officials explain focusing on the case of gold, should be seen as a process which extends beyond simply awarding permits and licenses:

... [formalization] seeks to integrate [artisanal and small-scale gold mining] ASGM into the formal economy. The process of formalization includes the development or adaptation of mining (and other) laws or policies to address the challenges of ASGM. A well-designed formalization process generates the enabling conditions for accountability within the sector so that it can ultimately be integrated into the formal economy. Formalization can only be successfully achieved if programmes and public policy deal with the different dimensions of ASGM activities simultaneously and in an integrated way. Legalization is just one dimension of the process of formalization. [UNEP 2012, p. 2]

Officials at the United Nations Economic Commission for Africa (UNECA), specifically those staffed in its African Minerals Development Centre, the main institutional vehicle guiding implementation of the AMV, are also on board with formalization. It appeared that a consensus was reached on its utility in this context at the international workshop, Building Capacity for Environmental Sustainability in Artisanal and Small Scale Mining in Africa, 24-26 May 2017, which was organized by the Centre's staff. The meeting, which ran for three days, sought 'to exchange on artisanal and small-scale mining frameworks and evidence-based decision making in the countries...by sharing country experiences on tools, case studies and best practices in order to identify gaps and opportunities for the development of Country Mining Visions that respond to the Sustainable Development Goals'. ${ }^{7}$ Reflecting on the subject, the Coordinator of the Centre conceded that whilst 'It has become a cliche to present formalisation as a silver bullet for challenges faced within ASM, whether environmental, financial, social or technical', and 'a misleading notion to view formalisation as the heart of addressing all and sundry major challenges in ASM...it does offer pathways that align to the AMDC [African Minerals Development Centre] championed "golden triangle" support for ASM' (UNECA, 2017c). The view here, however, is that this 'golden triangle' of 'three service pillars' (technical, finance and marketing), which UNECA officials argue have been 'distilled from the tenets of the AMV in espousing a sustainable ASM sector' (p. 6), are an insufficient pathway because they fail to connect comprehensively with the reasons why millions of people are confined to working in the sector's informal ASM 'spaces'.

On the one hand, the architects of the AMV and the Centre's staff do demonstrate an acute awareness of the factors contributing to ASM informality in sub-Saharan Africa. In addition to core AMV documentation being laced with references to, inter alia, ASM's growth being linked to poverty and its operators needing support, the Business Plan of the African Minerals Development Centre (UNECA, 2012) highlights very specific issues which only those with an intimate knowledge of the sector would be able to identify:

Artisanal and small-scale mining is beset by a number of challenges which prevent it reaching its full developmental potential. Many of these include inadequate policy and regulatory frameworks; the limited technical capacity of miners; lack of access to finance and appropriate technologies; and, regrettably, child labour issues. These challenges generally lock small-scale miners into a cycle of subsistence operations with significant negative consequences for the environment and human life. Further, the ASM sector is prone to trade in conflict minerals as many of the miners operate outside the law for various reasons. [p. 23]

But on the other hand, host governments have fallen considerably short under the direction of the AMV in their efforts to tackle these - systemic - problems. This seems to be a case of the breadth and

\footnotetext{
7 'Building Capacity for Environmental Sustainability in Artisanal and Small Scale Mining in Africa', www.uneca.org/publications/building-capacity-environmental-sustainability-artisanal-and-small-scale-miningafrica (Accessed 3 June 2018).
} 
rootedness of the informality found in the ASM sector in sub-Saharan Africa, which are held together by trust and dependence, having been misdiagnosed and potentially, ignored outright. Adams (2013) argues that 'Informality, at least in developing countries, appears to be less the result of cumbersome regulations and mistrust in public institutions and taxation, and more a result of significant pressures on job creation and sustaining livelihoods' (p. 1). In the case of ASM in sub-Saharan Africa, however, it is a combination of both: the 'inadequate and policy and regulatory frameworks' referred to above have created the informal 'spaces' within which today, most of the sector's activities are found and to where hundreds of thousands of people scramble in search of work. These experiences are to some degree in tune with how the Legalist school perceives informality, namely as the product of cumbersome regulation which gives rise to territories in which deeds, trust-based relationships and permits emerge which only prevail within their boundaries (see De Soto, 2000).

This raises an initial concern: how the architects of, and signatories to, the AMV, fail to make the connection between the growing numbers of participants in the region's informal ASM economy and the policy and regulatory frameworks in place for the sector. Here, 'inadequate policy and regulatory frameworks' qualify as the inappropriate permitting and licensing systems in place for ASM in subSaharan Africa, which is dissuading, rather than encouraging, individuals to mine legally. This was a problem which officials at the ILO drew attention to nearly two decades ago, in the landmark report, Social and Labour Issues in Small-Scale Mining (ILO, 1999), which argued that the sector is 'bedevilled with too many regulations that are mostly designed to constrain it' (np). Yet, with perhaps the exceptions of Tanzania and more recently, Zimbabwe, which have decentralized their licensing process for ASM and temporarily suspended payments on licenses, respectively, no country in subSaharan Africa has made much of an effort to simplify and/or reduce the costs of the sector's permitting processes. As Table 4 illustrates, in most of the region's countries where there is persistent poverty and the growth of the sector is believed to be driven by hardship, exorbitant fees continue to be charged and/or procedurally-complex application processes exist for licenses. But whilst AMV literature occasionally makes reference to inappropriate licensing for ASM, what is clear, judging by the pedestrian pace with which systems are being overhauled, is that there is a lack of understanding of how 'inadequate policy and regulatory frameworks' is contributing to the rootedness of the sector's informal dimension.

A second concern is the lack of effort that has been made since the launch of the AMV to create the necessary physical space to accommodate and nurture the expansion of a formalized ASM sector in sub-Saharan Africa. Where possible, countries in the region prioritize the expansion of large-scale mineral exploration and mining activities, which typically entails overhauling economic policies to include tax breaks to attract foreign investment. But an extractive industries-led development strategy, with, as Hilson (2018) puts it, a large-scale mining 'bias', ultimately requires a commitment to putting aside and leasing vast quantities of land to mineral exploration and mining companies for lengthy periods of time. There are a number of examples scattered across the literature which underscore the seriousness of the problem. A quick glance of the Flexicadastre system, which stores concession data for subscribers and projects these on to a country map, will illustrate clearly the extent of the problem in countries such as Zambia, DR Congo and Tanzania. The concern here, however, has more to do the haste with which concessions are demarcated. On the one hand, doing so puts host governments in a position to secure steady stream of revenue in the form of taxes, royalties and permit fees, with minimal effort. But on the other hand, having, in most cases, undertaken minimal geological work beforehand has meant that sizable sections of mineralized terrain (containing, for example, alluvial and near-surface hardrock deposits) appropriate for ASM but not appealing to the company have been included as part of these concessions. This has had the effect of 'insulating' existing ASM in these concessions, and in the process, 'creating' illegal or informal 'spaces'. 
Is the expectation that host African governments will develop the foresight needed to avoid such problems? Certainly, by carrying out the necessary geological work beforehand, ministries will put themselves in a position to identify areas appropriate for ASM activity and block them out, in the process establishing the foundation of a formalized sector and preventing these sections of land from being included as part of large-scale mining and mineral concessions. But it is unclear where the commitment needed to achieve this would come from, as most governments seem preoccupied with putting themselves in a position to generate more revenue from large-scale mining activities. This is reflected in most of the goals and objectives linked to the AMV, most of which are oriented around facilitating an 'Optimized share of revenue accruing from mineral resource extraction' (UNECA, 2017, p. 5). To provide an indication of the mindset, in the African Minerals Development Centre's Business Plan, developmental goals are segmented into key 'Results Areas', the first of which is 'Policy and Licensing', the justification for which, it is explained, being that 'the current approach of taxing the industry in order to obtain development revenue is not at all optimal' (UNECA, 2012, p. 20), and how 'improvement in the policy, legal and fiscal instruments for revenue maximization and increased investment in the mineral sector and the prevention of illicit financial flows' (UNECA, 2017a, p. 5) and would ensure, inter alia, that 'African countries receive an enhanced share of mineral revenue' (UNECA, 2012, p. 21). This exercise, however, would surely require committing even more land resources to make this happen.

It is unclear how the architects of the AMV see Boosting Artisanal and Small-Scale Mining as a realizable goal, given this priority. Moreover, asking the architects - African mine ministers - to change policies to accommodate ASM and in the process, potentially compromise their ability to extract revenue from large-scale activities, is unrealistic. Even the proposed geological work ('Results Area 2 - Geological and mining information systems') is more about broadening understanding of mineral wealth, specifically, the view that 'Enhanced use of geological and geospatial information to manage long-term developmental outcomes in African mining countries' (UNECA, 2012, p. 19). This may explain why 'Artisanal and Small-Scale Mining' is the fourth category of 'Results Areas': a possible reflection of its comparatively lower level of prioritization. Any commitment to Boosting Artisanal and Small-Scale Mining will require a far more integrated strategy which addresses the concerns of both sectors simultaneously.

This could explain why, despite evidence which points to ASM communities in sub-Saharan Africa being populated by a wide range of - predominantly poverty-driven - people, the AMV is working to promote a 'A mining sector that harnesses the potential of artisanal and small-scale mining to stimulate local and national entrepreneurship, improve livelihoods and advance integrated rural social and economic development' (UNECA, 2017a, p. 2). This a third major concern of the 'golden triangle' being promoted by the African Minerals Development Centre: as indicated at the outset of this paper, most of the individuals working in informal ASM 'spaces' in sub-Saharan Africa are necessity, rather than opportunistic, entrepreneurs. Sophisticated marketing and financial programs, therefore, would be inappropriate for most of the individuals employed in the sector; there is also the likely possibility of many of those driven to ASM leaving the sector - the struggling farmer, youths looking to secure enough money for their university passages and women looking to jumpstart a household enterprise - if 'empowered' or provided access to the support services which the AMV and ultimately, the Centre's management, are attempting to usher through for operators.

Fine-tuning the Centre's 'golden triangle', which is far from being a blueprint for localizing the SDGs for ASM, to emphasize the three-pronged approach put forward by McQuilken and Hilson (2016) would position governments in sub-Saharan Africa to address the aforementioned concerns by putting them closer to the informal 'spaces' communities they are looking to reach. The approach, described as a 'three-pronged strategy', comprises 1) 'Geological prospecting and land allocation' to identify areas, upfront, for ASM; 2) 'Access to finance' with a view to supporting the full spectrum of operators; 
and 3) 'Streamlined licensing' or making regulations and permitting processes more 'user friendly'. The 'golden triangle' being ushered through by the Centre is unlikely to spawn activities which demand that government officials connect with specific groups populating the informal 'spaces' found across sub-Saharan Africa, including women. A combination of a lukewarm commitment to Boosting Artisanal and Small-Scale Mining, a preoccupation with fostering the growth of, and maximizing revenue from, large-scale mining, and a general limited level of understanding of the dynamics of ASM in sub-Saharan Africa could lead to the AMV's signatories implementing strategies which have an adverse impact on the women working in the sector's informal 'spaces'. As the two brief country case studies presented in the next section of the paper illustrate, many women have adjusted to life in these informal 'spaces', and any move made to support them, however genuine, could upset the equilibriums of their work lives. Before undertaking any intervention made to support women under the auspices of the AMV, in particular, its pillar, Boosting Artisanal and Small-Scale Mining that speaks to the SDGs, therefore, host governments should first study more closely the dynamics of informal ASM 'spaces', and the lives of the women who populate them. 
Table 4: Licenses and permits for ASM in selected countries in sub-Saharan Africa

\begin{tabular}{|c|c|c|c|c|c|c|}
\hline Country & $\begin{array}{l}\text { \% Population } \\
\text { Living below } \\
\text { poverty line, } \\
2006-2014 \\
\end{array}$ & $\begin{array}{l}\text { \% Population } \\
\text { on less than } \\
\text { US\$1.90/day, } \\
2006-2014 \\
\end{array}$ & License & Cost & Duration & Details \\
\hline Ghana $^{8}$ & 24.2 & 25.2 & $\begin{array}{l}\text { Small-Scale Mining } \\
\text { License }\end{array}$ & $\begin{array}{l}\text { Varies but typically, } \\
\text { more than US\$1000 }\end{array}$ & $\begin{array}{l}\text { 3-5 years } \\
\text { with the } \\
\text { possibility } \\
\text { for } \\
\text { renewal, } \\
\text { covering } \\
\text { an area up } \\
\text { to } 25 \text { acres }\end{array}$ & $\begin{array}{l}\text { Prospective licensees are required to produce } \\
\text { detailed surveying plans now cost on average } \\
\mathrm{GH} \nsubseteq 1000 \text { (approximately GH } \$ 800 \text { for the maps and } \\
\mathrm{GH} \$ 200 \text { for a licensed surveyor's signature) before } \\
\text { the relevant local government officer can be } \\
\text { approached; a GH } \$ 100 \text { Application fee and a } \\
\text { GH } ₫ 250 \text { Processing fee must be paid; and GH } \$ 550 \\
\text { Consideration fee covered. The Government of } \\
\text { Ghana also - rather inexplicably - recently increased } \\
\text { the fee for what is widely believed to be an } \\
\text { unnecessary Environmental Protection Agency } \\
\text { permit, from GH } \$ 750 \text { to GH } \$ 9600 \text {. }\end{array}$ \\
\hline Liberia & 63.8 & 68.6 & Class B License & $\begin{array}{l}\text { The fee for a Class B } \\
\text { License is } \\
\text { US\$10,000 }\end{array}$ & $\begin{array}{l}\text { One year } \\
\text { for an area } \\
\text { of up to } \\
100 \text { acres } \\
\text { with } \\
\text { annual } \\
\text { license fee } \\
\text { of } \\
\text { US\$5000 }\end{array}$ & $\begin{array}{l}\text { Class ' } \mathrm{B} \text { ' license holders are permitted to conduct } \\
\text { semi-mechanized mining and to sell production } \\
\text { internally and externally. This license can be held by } \\
\text { both Liberians and foreigners. The problem in } \\
\text { Liberia is that holders of a Class C License, which } \\
\text { costs an affordable US\$150, are not permitted to use } \\
\text { machinery. }\end{array}$ \\
\hline $\begin{array}{l}\text { Sierra } \\
\text { Leone }\end{array}$ & 52.9 & 52.3 & $\begin{array}{l}\text { Small-Scale Mining } \\
\text { License }\end{array}$ & $\begin{array}{l}\text { A new application } \\
\text { fee is US\$1000, } \\
\text { Renewal is also } \\
\text { US\$1000, and the } \\
\text { Annual license fee is } \\
\text { US\$800/ha A small- } \\
\text { scale mining license }\end{array}$ & $\begin{array}{l}\text { It is valid } \\
\text { for a } \\
\text { period of } \\
\text { three } \\
\text { years, and } \\
\text { is subject } \\
\text { to further }\end{array}$ & $\begin{array}{l}\text { Small-scale mining permits the use of mechanized } \\
\text { equipment but does not allow mineral extraction } \\
\text { below a depth of } 20 \text { meters, or cannot involve the } \\
\text { sinking of shafts, drilling and other underground } \\
\text { operations. The license fee is the first hurdle, as a } \\
\text { small-scale permit requires completion of } \\
\text { Environmental Impact Assessment, a procedure that }\end{array}$ \\
\hline
\end{tabular}

\footnotetext{
${ }^{8}$ At the time of writing, the conversion rate was approximately US\$1: GH $₫ 4.75$
} 


\begin{tabular}{|c|c|c|c|c|c|c|}
\hline & & & & $\begin{array}{l}\text { covers a land area } \\
\text { between one } \\
\text { hectare and no } \\
\text { more than } 100 \\
\text { hectares. }\end{array}$ & $\begin{array}{l}\text { renewal of } \\
\text { the same } \\
\text { duration } \\
\text { at any } \\
\text { time. }\end{array}$ & $\begin{array}{l}\text { can costs tens of thousands of US dollars. This is why } \\
\text { most legal miners in the country hold an Artisanal } \\
\text { Mining License, which costs Le250,000 } \\
\text { (approximately US\$35). Holders of this license, } \\
\text { however, are prohibited from using machinery. } \\
\text { In addition, a small-scale mining license is only } \\
\text { granted to a business entity in which Sierra Leoneans } \\
\text { have at least a } 25 \text { percent shareholding. Small-scale } \\
\text { miners must enter into a Community Development } \\
\text { Agreement (CDA) with the Primary Host Community, } \\
\text { with the miner annually spending no less than } 1 \% \text { of } \\
\text { the gross revenue on CDA contributions. }\end{array}$ \\
\hline Zambia & 60.5 & 64.4 & $\begin{array}{l}\text { Small-Scale Mining } \\
\text { License }\end{array}$ & $\begin{array}{l}10 \text { years; max } 10- \\
\text { year renewal }\end{array}$ & 400 ha & $\begin{array}{l}\text { Zambia also has an Artisanal Mining License but is } \\
\text { covers a maximum area of } 6.68 \text { ha for a period of } \\
\text { two-years, and a maximum } 2 \text { years per renewal. }\end{array}$ \\
\hline Zimbabwe & 72.3 & 21.4 & Ordinary License & Two years, US\$200 & $\begin{array}{l}\text { Covers } 10 \\
\text { ha }\end{array}$ & $\begin{array}{l}\text { Any person over the age of } 18 \text { and who is a resident } \\
\text { of Zimbabwe can apply for this license. The main } \\
\text { problem in Zimbabwe has been the additional fees } \\
\text { prospective licensees must pay, in particular, } \\
\text { US\$4000 for an Environmental Impact Assessment } \\
\text { certificate. At the time of writing, as part of an } \\
\text { ongoing campaign to encourage miners apply for } \\
\text { their licenses, the government had waived all of the } \\
\text { fees linked to applications. }\end{array}$ \\
\hline
\end{tabular}

Sources: Government of Liberia, 2010; Spiegel, 2015; UNDP, 2016b; ZEPARU, 2016; 'Govt shelves mining fees for small scale miners',

www.zimbabwesituation.com/news/govt-shelves-mining-fees-for-small-scale-miners/ (Accessed 8 June 2018); Hilson et al., 2018; 'National Minerals Agency: First Schedule - Fees', http://www.nma.gov.sl/home/fees/ (Accessed 9 July 2018); 'Mining Licenses Permits',

http://www.zda.org.zm/cost/en/Cost\%200f\%20Doing\%20Business/Appendix1/Minning\%20Licences\%20Permits 


\section{Two Country Case Studies: Sierra Leone and Zambia}

This section of the paper draws on findings from ongoing research on ASM and women in Sierra Leone and Zambia. Both countries are signatory to the AMV and has committed to formalizing ASM. But despite ongoing efforts, the sector remains largely informal and is populated heavily by women in each country Figure 2).

The informality of, and manoeuvrability these women enjoy in, these 'spaces' is a direct result of ASM's policy treatment. In each country, it is neglected, and even where it is licensed, it must be considered 'quasi-informal' because the authorities fail to adequately regulate activities, and operators still struggle to access the support services which are generally made available to the typical small and medium sized businesses. Whilst Sierra Leone and Zambia have very different mineral landscapes, in both cases, women have acclimatized quickly to the dynamics of the informal ASM economy. Echoing points made in the paper thus far, any effort to reach these women must, therefore, take stock of their livelihoods and experiences, or they could have an adverse impact on their livelihoods.

Figure 2: A previewing the two study countries, Sierra Leone and Zambia

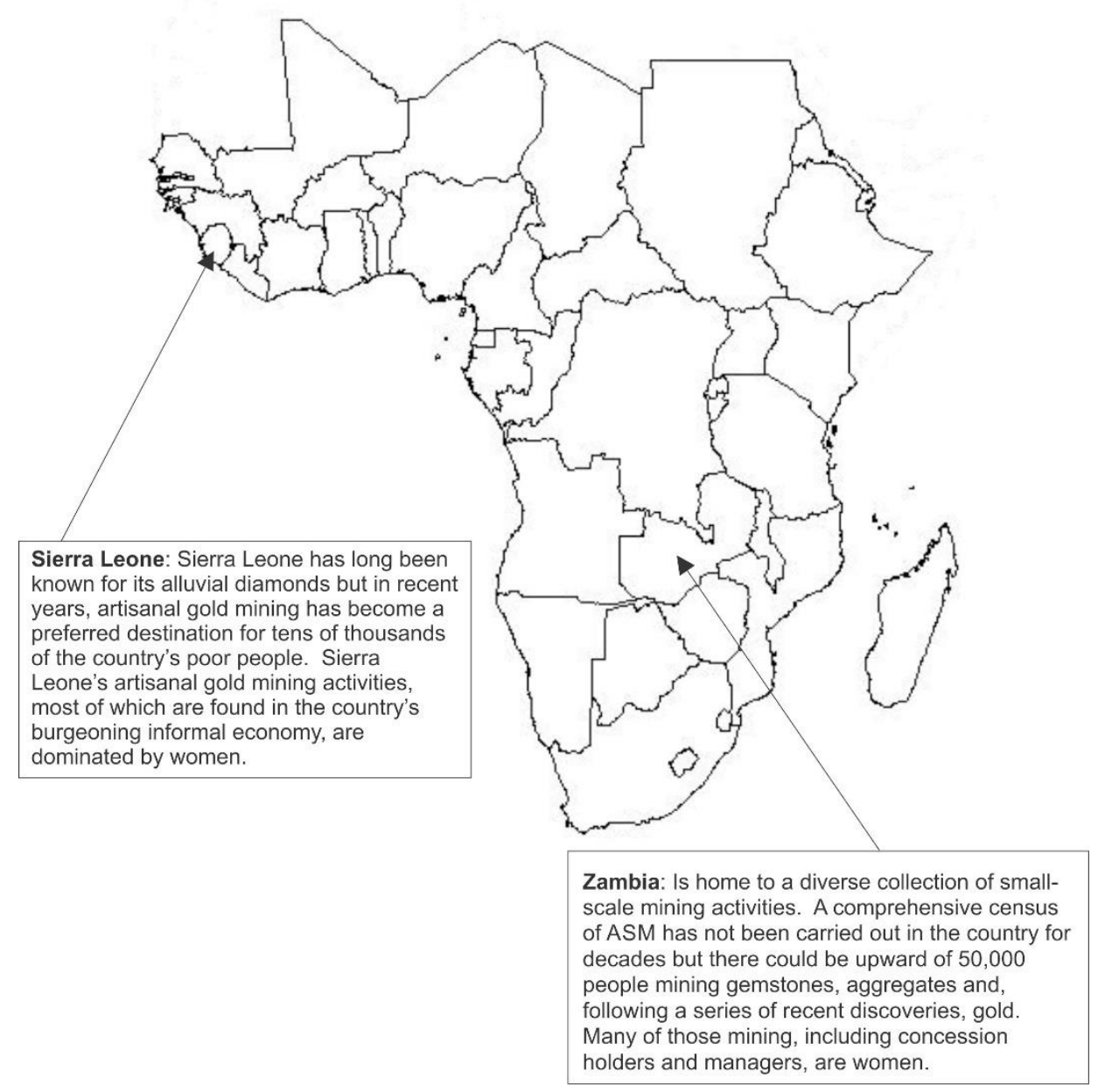




\subsection{Sierra Leone}

In Sierra Leone, diamonds have long been the central focus of the country's burgeoning post-war mining sector. But recent research has revealed that artisanal gold mining makes an important, but overlooked, contribution to the rural economy (Maconachie and Hilson, 2018; Maconachie and Hilson, 2011; Maconachie, 2011; Cartier and Burge, 2011). Although the informal and unregulated nature of artisanal gold mining operations has meant that diggers are often able to take advantage of the sector's low barriers to entry, many informal miners are adversely incorporated into exploitative relationships with buyers and middlemen, often becoming trapped in cycles of poverty and indebtedness. Much evidence now suggests that not only would a formalized artisanal gold mining economy provide much-needed jobs in an employment-constrained economy, a development that would help to reintegrate marginalised youth into the workforce but would also play a critical role in generating much-needed capital to contribute to rural livelihood security. Women, in particular, could benefit significantly from appropriate formalization schemes, both directly and indirectly.

Gold panning is mainly a female-dominated activity in Sierra Leone, and although returns are small, the sector's operations can be a steadier and more reliable source of income than diamond mining. In sharp contrast to the findings put forward in the literature and many of the experiences shared in the previous section of the paper from Ghana, DR Congo and East Africa, some reports suggest that, in Sierra Leone, as much as 90 per cent of gold prospecting is undertaken by women; many camps are also headed by women. ${ }^{9}$ Research being undertaken by the authors in around the town of Makeni in Tonkolili District, for example, has revealed that, women, working methodically in the shadow of young males' pursuits of finding a 'winning diamond' and driven by necessity, have organized themselves into groups to pan the sediments of the Pampana River and the tailings of diamond gravels, with nothing more than rudimentary implements such as shovels and calabashes. In the process, these women 'have stumbled on a potentially huge untapped resource which could, if marketed and planned efficiently, provide them with a reliable source of income and financial independence in a war-ravaged country'. ${ }^{10}$ In the aftermath of the recent Ebola crisis which gripped West Africa for three years, it would seem that this resource is more valuable than ever for helping households recover from the shocks and stresses of the crisis (Maconachie and Hilson, 2018). But as recent research has revealed, illicit gold mining continues to be widespread: the vast majority of female panners operate without a license. Many women interviewed to date have reported that, in the absence of formalized structures, informal arrangements with landowners must be forged, whereby, extortionate fees for 'water rights' are paid to mine a river bank.

Due to its informality, artisanal gold mining links closely to, and complements the activities of, the agricultural cycle. As recent research undertaken on diamond mining in the Eastern Province of the country has revealed, and reinforcing point raised earlier, seasonality remains an important determinant in understanding the circular migration patterns that define the 'inter-locking nature' of mining and farming in Sierra Leone (Binns and Maconachie, 2006; Maconachie and Binns, 2007; Maconachie, 2008). Diamond mining and farming have long 'dovetailed' one another, the former undertaken in the dry season when river levels are low, and the latter carried out during the rainy season. However, artisanal gold mining may also be strongly linked to seasonal patterns in the local rural economy, with panning activities being more prevalent at certain times of the year. Focus group discussions and semi-structured interviews with miners in Tonkolili District confirmed this. Most interviewees reported that they engage in small-scale gold mining between the dry season months of February and May, during which time, many pan along the Pampana River six days a week. Women reported that during a 'productive week', upward of 10 carats of gold could be panned. This gold could

\footnotetext{
99 'Sierra Leone Eyes a Golden Future', http://news.bbc.co.uk/1/hi/business/5262960.stm (Accessed 4 June 2018).

${ }^{10} \mathrm{lbid}$.
} 
then be sold at local markets on Thursdays, where dealers - often from as far away as Guinea - come to buy. Reports from women also indicated that this capital makes an important economic contribution to the household; is used to pay for a variety of household expenses, such as school fees and supplies and medicines; and, perhaps most importantly, in many cases, is reinvested back into farming.

Many women interviewed also recounted that their gold winnings had provided the necessary startup capital to create farming associations, which had proved vital in 'jump-starting' agricultural activities and rebuilding trading networks damaged during the war. Previous work carried out in Sandor Chiefdom in the Eastern Province of Sierra Leone has shown that a major barrier to rejuvenating agriculture was the inability of farmers - due to their shortages of capital - to activate traditional labour cycles (Maconachie, 2008). As Fanthorpe (2007) explains, the revival of reciprocal labour companies, cooperative associations and rotational credit clubs has proved vital in reconstructing the social networks that flourished in the rural economy during the post-war period. Gold mining appears to have helped many people overcome this obstacle.

Many women miners have revealed that their earnings from gold mining were being used to finance agricultural 'businesses' and trading ventures. Several interviewed described how, with the income derived from gold panning, they were able to purchase a wide range of fresh foodstuffs from nearby villages, including cassava, aubergines, oranges, limes and mangoes, which they would then transport to Freetown to sell for much higher prices. Many of these rural entrepreneurs were well aware that they could make considerable profits through such trading endeavours. The demand for fresh agricultural produce in Freetown has increased considerably during the post-conflict period, which, in turn, has stimulated the growth of a highly organised network for the marketing of food crops in rural areas. The emergence of small-scale gold mining has helped deliver a significant share of this produce to market: many of the women miners interviewed reported having established strong personal contacts with farmers. Certain women miners have even been able to offer producers incentives in the form of credit, in return for a guarantee of crop purchase at harvest time.

In Sierra Leone, it is without doubt that the artisanal gold mining sector has a prominent gender dimension but the current policy machinery in place has done little to help entrepreneurial women harness fully the benefits of this valuable resource. While the country has embraced SDG 5 in many of its rural development policies and programmes, and it is widely acknowledged that increased financial stability and independence for women are needed to challenge deep-seated gender norms, influence unequal power structures and promote women's rights, more needs to be tackle these entrenched problems in the artisanal mining sector. For example, women engaged in gold mining should be empowered as concession holders, a move which would have ripple effects, facilitating improved agricultural productivity and food security, and alleviating rural poverty even further. But at the same time, the current policy machinery, which focuses heavily on diamonds and not particularly on gold, has also enabled women to emerge in the informal 'space' and seize control of the latter. Women have creatively used the ability to move freely in the informal gold mining 'space' to support their households and reinvest small earnings into other economic activities. Without a proper appreciation of the benefits this activity yields for rural households in Sierra Leone, a gendersensitive ASM formalization program implemented under the auspices of the AMV and which speaks to the SDGs could draw unnecessary attention to, and subsequently have deleterious impacts on, an otherwise 'successful' enterprise.

\subsection{Zambia}

In Zambia, it is more of a case of women manoeuvring in a quasi-informal ASM 'space', with some, in the absence of a consistent government presence, gaining elite status at the expense of many others. 
Any formalization program and support intervention for these women would, therefore, need to take stock of these very significant variations, depending on the objective.

Women constitute a significant proportion of Zambia's ASM sector. Although Dreschler (2001), in 2001, estimated that only 30 percent of ASM operators in Zambia are women, it is likely that this number has increased markedly over the years, and is at least 50 percent today in particular branches such as amethyst. Most Zambian women are driven into - at time, perilous working conditions of ASM with hopes of securing better incomes for their families and by limited alternative livelihood opportunities, a manifestation of what many would consider the 'poverty-driven' narrative in this context. In Zambia, old myths once held about the impropriety of women's involvement in mining and suggestions that when women enter excavated pits, minerals 'hide themselves', have since given way to partnerships between men and women, and indeed their dominance in the sector in several cases. ${ }^{11}$ As ongoing research has revealed, Zambian women miners, particularly in the gemstone sector, are engaged in a range of roles, from digging for minerals, through hauling, sorting, grading and value-addition, to financing and trade. Some women also own and manage their own mines, although there are few examples of this.

Women's involvement in the ASM sector, however, still tends to be homogenized in policy discussions, with the underlying assumption that once the distinction is drawn between them and men, variation is sufficiently accounted for. Without further nuancing these dynamics, any move made under the auspices of the AMV to connect with ASM operators in Zambia could lead to further homogenization of women's roles in the sector. Significant differences between women, therefore, often go overlooked in program design at the international, regional and national levels and by civil society groups. The many variations among women engaged in ASM in Zambia are evident by the roles they occupy in the sector, which can be diverse; their socio-economic statuses; and the levels of power and vulnerability arising from differences in education and social networks. The paucity of information on the sector in general has meant that even comprehensive policy interventions such as AMV often overlook the nuances of female involvement in the sector in countries such as Zambia.

As is the case in other African contexts, in Zambia, the AMV outlines what appears to be a comprehensive plan for the transformation of ASM, which includes fostering support to women. Several key recommended actions proposed under the AMV, if implemented, could significantly transform Zambia's ASM sector. The AMV's recognition of the finite nature of ASM and the need to train ASM operators in alternative livelihoods, is, for instance, an important step in the case of the low value minerals being mined in Zambia. Many low-income women within the country capital of Lusaka who have relied on digging and crushing stones that supply the city's booming construction industry have found themselves displaced by the widespread construction of houses and roads. As their activities occur most in (quasi-)informal 'spaces' and on untitled land, it has made them particularly vulnerable to displacement without recourse. Moreover, the entrance of foreign entrepreneurs, including the Chinese, who have greater access to finance and technology, has undercut the profitability of these women, forcing many to abandon the activity. The remaining women who persist in the activity have become traders who buy machine-extracted rocks for resale from mostly foreignowned, male-operated, mechanized enterprises and earn lower incomes. Beyond the low value minerals sector, similar challenges from the finite nature of minerals such as gemstones, similarly pose a threat of displacement of actors. The need for training and investment into diversified livelihoods as proposed by the AMV is therefore an important step, but one which receives limited attention in the Zambian case. Other critical areas for action identified by the AMV include the need for effective,

11 Interview, woman miner, 4 December 2017, Lusaka. 
accessible, financial schemes for ASM operators, opening of market opportunities, strengthening of ASM associations and progress towards gender equity and the empowerment of women.

While the above interventions hold promise for women in the sector, they overlook the important element of access to the poorest women who are most in need and assume homogeneity among women, which is not the case. In the Zambian case, efforts to train women, provide them with financial access, open market opportunities to them and offer general empowerment, particularly in the gemstone sector, have, over the years, been captured by a cartel of powerful elites, at the expense of the poor majority. These women are often better educated, possess social connections to those in political power and/ stronger financial positions, have a higher socio-economic status and are most familiar with how to navigate the workings of the NGO, government and donor worlds. In this quasi informal 'space', these elite ASM women largely position themselves as gatekeepers to the 'vulnerable women of the sector' through women's associations and arise as champions in favour of those who cannot speak for themselves. They have come to be heavily relied upon by the government, NGOs and donors as the key conduit through which benefits such as those highlighted in the AMV can be best transmitted to the masses. As one government official rightly observed, the government is highly centralized and so relies on actors with links to players on the ground. ${ }^{12}$ In the Zambian case, however, these elite women have mostly used the benefits from government and donor agencies for personal gain. In the case of training opportunities, for example, senior officials interviewed at both in the Ministry of Mines and Minerals Development and the Ministry of Commerce expressed concern that the same women seem to be attending training workshops and that information on assistance seemed to be controlled by these individuals and sporadically distributed within their narrow networks. ${ }^{13}$ Even in cases where these association leaders have responded to calls to bring their members to events by donors, individuals invited do not always represent bona fide members. Interviews with women stonecrushers in Lusaka, for instance, revealed a disillusionment by these women who had previously been invited to meetings and asked to be photographed with their babies at stone-crushing sites with a view of receiving support. They, however, expressed dismay that the individuals who promised support never returned and so are now reluctant to speak to outsiders because they feel their poverty is being used for the benefit of unscrupulous actors. ${ }^{14}$ Such reports were confirmed by former members of the women's association who have since left the association due to such unscrupulous practices..$^{15}$ It is therefore critical that research be carried out on who the participants in the sector are, how best they can be reached by interventions and who is best positioned to deliver the outlined interventions. Otherwise, even in cases where countries like Zambia seek to open market access to poor women, these benefits will likely be captured by elites.

Apart from potential dangers that arise from failures to correctly identify needy players in the sector as well as devise the appropriate conduits for delivering support, there are the potential costs of formalization, as envisioned by the architects of the AMV, which poor women would be asked to cover. Positive measures such as stronger regulation and enforcement of environmental, occupational, health and safety standards are indeed crucial. Women engaged in Lusaka's low value mineral sector (stone crushing), for instance, identified frequent injuries that in turn kept them from productive activity and lowered income earning potential, a poverty-trap dynamic identified in other studies (e.g. Hilson, 2012). Environmental challenges that arise from the activity are also welldocumented (Hilson, 2002). However, safety gear and adoption of technology that assures greater

\footnotetext{
12 Interview, government official 16 July 2018, Lusaka.

${ }^{13}$ Interview, government official, 16 July, 2018, Lusaka.

${ }^{14}$ Interview, women stone crushers, 20 July 2018, Kalingalinga, Lusaka.

15 Interviews, women gemstone jewellers, 18 July 2018, Lusaka.
} 
occupational safety and health all require financial capacity. Operationalizing the ideas enshrined in the AMV, must therefore be undertaken in a comprehensive manner, in which regulation and safety standards are enforced in tandem with assessments of the financial capability for miners.

This should also extend to trading rules. In Zambia's amethyst sector, a significant number of women make a living from informal trading. Field visits to Zambia's Southern Province, specifically Mapatizya, where amethyst is mined, for instance, revealed that several women are involved in purchasing small quantities of amethysts sold by informal miners and aggregating these into larger consignments which are then sold to external buyers who come to the mines from the city or other countries. Such subsistence traders typically lack trading licences and do not have the finances or know-how to acquire them. While the majority of the men similarly lack trading licences, a few of them expressed some knowledge of licencing processes and indicated that they had acquired a licence that had subsequently expired. Acquisition of licences by the poorest women, therefore, currently poses a challenge. Once again, the more educated, elite category women of women would stand to benefit the most if informal trading rules were strictly enforced. These women already hold mining and trading licences and are engaged in selling their minerals in the city as well as internationally; they would be further empowered by the elimination of informal trading by the poorer women who present competition. Reiterating the main message conveyed in this paper, efforts aimed at facilitating formalization of trading should, therefore, take into account the positions of such women and seek to ensure that they are empowered to secure needful licences and protected from descending into joblessness and poverty.

On the whole, the prevailing dynamics of Zambia's ASM sector show that knowledge of the sector's organizational structures and the positionality of various women within it is essential in the design of formalization interventions. Many are clearly benefitting from the policy treatment of the sector and the freedom to move in a quasi-informal 'space', specific dynamics which will demand particular sets actions if the working conditions and livelihoods of those populating certain groups - in this case, women at different hierarchies of the labour structure - are to improve. Ongoing research in both Zambia and Sierra Leone has captured in some detail the roles played by women working in informal ASM 'spaces', and how this work has impacted their livelihoods. The findings complement those shared by other scholars and overall, the narrative is much more nuanced than what continues to be projected about women in ASM in sub-Saharan Africa.

\section{Concluding Remarks}

This paper began by explaining why informal ASM activity has expanded so rapidly in sub-Saharan Africa, before drawing attention to the important - albeit, poorly studied - roles women play in the sector. On the whole, women do struggle to ascend to top positions in the sector but do earn more as employees at or around mines than they could possibly earn elsewhere. Whilst women take enormous risks, often working in dangerous conditions and subjecting themselves to abuse, to earn this money, many would believe these efforts to be worthwhile because of the potential gains made and ultimately, the contribution they are able to make to their households. These are truly unmonitored 'spaces' for which there is an element of unpredictability, as shown with the two cases of Sierra Leone and Zambia: in both instances, in the absence of a government presence, women have established a presence in, and gained control of, informal ASM activity, although in the latter, there has been a much more visible pattern of elites emerging. It is, however, these dynamics which should be the focus of any effort aimed at Boosting Artisanal and Small-Scale Mining. 
The paper then turned to whether host African governments are in a position to achieve this. Most are signatory to the AMV, which champions its own blueprint of mining-led development in the region, which includes an uninspiring - and possibly, inappropriate - strategy for its artisanal and small-scale segment. Conceived by the 'African ministers responsible for mining', the AMV is built mostly around extracting a greater share of revenue from large-scale mineral exploration and mining activities, most of which are driven by foreign investment. This reflects the large-scale mining 'bias' rooted in the policymaking spheres of most states in sub-Saharan Africa. If, despite the orientation of the region's mining development policy toward large-scale mineral extraction, the goal is to support women engaged in artisanal and small-scale activities in ways that speak to the AMV's goal of Boosting Artisanal and Small-Scale Mining, then several hurdles must be overcome and new commitments made.

The first is ensuring that the schemes being installed speak specifically to an SDG framework - itself ambiguous - which will shape global development policy until at least 2030. As explained, operationalizing the SDGs at the local level will requires considerable fine-tuning, as they are very macro and high-level in their orientation and, particularly pertinent in this case, offer little guidance on how to address the concerns of the informal sector. Following the UNDP's Roadmap for Localizing the SDGs: Implementation and Monitoring at Subnational Level (UNDP, 2016c) whilst simultaneously embracing SDG 5 in its entirety would be a logical starting point. The AMV certainly permits signatories to be flexible in their approaches to designing mining-led development strategies. But the challenge here is developing policies and schemes under an initiative - that is, the AMV - that was designed before the SDGs were even conceived; this is bound to result in problems. Among the more legitimate concerns that have been raised about the AMV is it not being particularly comprehensive on the subject of gender. As Valiani (2015) explains, 'The absence of women's' rights or feminist organisations - not to mention mining-affected peoples' groups - within this African Union led mining policy initiative is a reflection of the relative lack of political organisation among these segments of African societies' (p. 5). This is an obvious problem, given that the SDGs are built heavily around the gender theme but again, come up short when it comes to localizing this framework. If the goal is to implement a formalization scheme that is capable of reaching women in informal ASM 'spaces', then major adjustments must be made, in light of the limitations of both of these policy frameworks, which do not complement one another fully.

The second is the need to reconcile conflicting ideologies. On the one hand, the AMV is very much build around extracting more revenue from large-scale mining activities, which, as explained, host governments are very keen to facilitate the growth of. This will require committing even more lands to developing a sector that requires vast terrain to be awarded to mineral exploration companies to bring a large-scale extraction project to fruition. But on the other hand, Boosting Artisanal and SmallScale Mining will require a similar level of commitment, in particular identifying areas that contain the deposits which are appropriate for artisanal workings. In countries which have a large-scale mining 'bias', however, the level of commitment needed to reconcile these two goals is lacking, specifically, pursuing both objectives simultaneously under a more integrative development strategy, under which the development of both sectors are promoted concurrently. In the case of ASM, this will require being more proactive with the demarcation of areas suitable for activity to ensure that they are not included, needlessly, as part of the concessions awarded to mineral exploration and mining companies.

A final concern is the lack of data. Despite meandering thematically at times, the paper has remained steadfast in its conviction on women's engagement in ASM across sub-Saharan Africa: there are simply insufficient data on hand to draw accurate conclusions about their work in the sector's informal 'spaces'. The recurring narrative is that they are being exploited, are subjected to violence and struggle to secure the top positions in the sector. Whilst this may indeed be the case, these are the 
hallmarks of the region's informal economy. Many women are willing to take the risks linked to this employment because of the financial benefits to be gained and the lack of alternative employment; their growing presence in the sector is a testament to its poverty-driven nature. As a starting point, policymakers are advised to acquaint themselves with the dynamics of the region's informal economic itself, which would offer important clues on the drivers of ASM's growth, in particular, the persistence of the sector's informal activities. An additional very important task is the need for more data on women miners themselves. The World Bank's Rapid Assessment Toolkit (Eftimie et al., 2012) provides valuable guidance on this front, highlighting the appropriate questions to ask and clues on how to gather specific data. This would, however, likely reveal how, in sharp contrast with the ideologies underpinning the pillar Bolstering Artisanal and Small-Scale Mining, that most are necessity, rather than opportunistic, entrepreneurs. It is this information that is needed if robust ASM formalization strategies are to be developed in sub-Saharan Africa, particularly if they are to reach and benefit women.

Overall, this paper has reinforced how little is known about informal ASM 'spaces' in sub-Saharan Africa, and, in particular, the women who populate them. 


\section{References}

Adams, A.V., de Silva, S.J., Razmara, S. 2013. Improving Skills Development in the Informal Sector: Strategies for Sub-Saharan Africa. The World Bank, Washington DC.

African Development Bank. 2011. African Development Report 2011. African Development Bank, Tunis.

Africa Mining Vision (AMV). 2009. Boosting Artisanal and Small-scale Mining. Africa Mining Vision, African Union, Addis Ababa.

Ahwireng-Obeng. F. 1993. Gender, Entrepreneurship and Socioeconomic Repatriation in South Africa. The Review of Black Political Economy 22(2): 151-165

Alpan, S. 1986. The Role of Government in Promoting Small-Scale Mining. Natural Resources Forum 10(1): 95-97.

Armah, F.A., Boamah, S.A., Quansah, R., Obiri, S., Luginaah, I. 2016. Working conditions of male and female artisanal and small-scale goldminers in Ghana: Examining existing disparities. The Extractive Industries and Society 3(2):464-474.

Attaran, A. 2005. An Immeasurable Crisis? A Criticism of the Millennium Development Goals and Why They Cannot Be Measured. PLoS Medicine 2(10): 955-961.

Banchirigah, S.M. 2006. How have Reforms Fuelled the Expansion of Artisanal Mining? Evidence from Sub-Saharan Africa. Resources Policy 31(3): 165-71.

Banchirigah, S.M. 2008. Challenges with eradicating illegal mining in Ghana: a perspective from the grassroots. Resources Policy 33: 29-38.

Barry, M. (Ed.). 1996. Regularizing Informal Mining. A Summary of the Proceedings of the International Roundtable on Artisanal Mining. Organized by the World Bank, 17-19, May 1995, Industry and Energy Department Occasional Paper No. 6, Washington, DC.

Bashwira, M.-R., Cuvelier, J., Hilhorst, D., van der Haar, G. 2014. Not only a man's world: Women's involvement in artisanal mining in eastern DRC. Resources Policy 41(1): 109-116.

Bathé, M. 2016. The doubtful business of extracting gold: Challenges of environmental law in Mali's mining sector, pp. 121-144, in Competing Norms: State Regulations and Local Praxis in sub-Saharan Africa (eds. M. Diawara and U. Röschenthaler), University of Chicago Press, Chicago.

Bhatasara, S. 2013. Black granite mining and the implications for the development of sustainability in Zimbabwe: The case of Mutoko communities. Environment, Development and Sustainability 15 (6): 1527-1541.

Bhave, M. P. 1994. A Process Model of Entrepreneurial Venture Creation. Journal of Business Venturing 9: 223-242.

Binns, T. and Maconachie, R., 2006. Post-conflict reconstruction and sustainable development: diamonds, agriculture and rural livelihoods in Sierra Leone. International Journal of Environmental, Cultural, Economic and Social Sustainability 2(3): 205-216. 
Burke, G. 1997.Policies for small-scale mining: The need for integration. Minerals and Energy - Raw Materials Report 12(3): 11-14.

Buss, D., Rutherford, B., Hinton, J., Stewart, J., Lebert, J., Cote, G.E., Sebina-Zziwa, A., Kibombo, R., Kisekka, F. 2017. Gender and Artisanal and Small-Scale Mining in Central and East Africa: Barriers and Benefits. Institute for the Study of International Development (IDRC) Working Paper GWP-20172, IDRC, Ottawa.

Buxton, A. 2013. Responding to the challenge of artisanal and small-scale mining. How can knowledge networks help? International Institute for Environment and Development, London.

Cartier, L and M. Burge. 2011. Agriculture and artisanal gold mining in Sierra Leone: Alternatives or complements? Journal of International Development 23: 1080-1099.

Chen, M. 2008. Women and Employment in Africa: A Framework for Action. Danish Foreign Ministry, Copenhagen.

Chen, M.A. 2001. Women in the informal sector: a global picture, the global movement. SAIS Review 21(1): 71-82.

Cheung, O. 2014. Are we seeing 'necessity' or 'opportunity' entrepreneurs at large? Research in Business and Economics Journal 9: 1-26.

Chitsilke, C. 2001. Cultural as a barrier to women's entrepreneurship: Experience from Zimbabwe. Gender \& Development 8(1): 71-77.

Chichester, O., Pluess, J.D., Taylor, A. 2017. Women's Economic Empowerment in Sub-Saharan Africa: Recommendations for the Mining Sector. BSR, New York.

Danquah, M., Osei-Assibey, E. 2018. The Extent and Determinants of Tax Gap in the Informal Sector: Evidence from Ghana. Journal of International Development (In Press).

Davidson, J. 1993. The transformation and successful development of small-scale mining enterprises in developing countries. Natural Resources Forum 17(4): 315-326.

De Lattre, A. 1990. The small business in the Sahel. OECD Observer 163: 31-35.

De Soto, H. 2000. The Mystery of Capital: Why Capitalism Triumphs in the West and Fails Everywhere Else. Basic Books, New York.

Dessertine, A. 2016. From pickaxes to metal detectors: Gold mining mobility and space in Upper Guinea, Guinea Conakry. Extractive Industries and Society, 3 (2), pp. 435-441.

Dhar, S. 2018. Gender and Sustainable Development Goals. Indian Journal of Gender Studies 25(1): 47-78.

Dieterich, C., Huang, A., Thomas, A.H. 2016. Women's Opportunities and Challenges in Sub-Saharan Africa's Job Markets. International Monetary Fund Working Papers No. 16/118, International Monetary Fund, Washington DC. 
Diamond Development Initiative (DDI). 2009. Artisanal diamond mining and gender: An overview. Policy Backgrounder. DDI, Ottawa.

Dreschler, B. 2001. Small-scale Mining and Sustainable Development within the SADC Region. Working Paper 84, Mining, Minerals and Sustainable Development (MMSD) Project, International Institute for Environment and Development (IIED), London.

Dube, G., Casale, D. 2016. The implementation of informal sector taxation: Evidence from selected African countries eJournal of Tax Research 601-623.

Eftimie, A., Heller, K., Strongman, J. 2009. Gender Dimensions of the Extractive Industries: Mining for Equity. The World Bank, Washington DC.

Eftimie, A., Heller, K., Strongman, J., Hinton, J., Lahiri-Dutt, K., Mutemeri, N., Insouvanh, C., Sambo, M.G., Wagner, S. 2012. Gender Dimensions of Artisanal and Small-Scale Mining: A Rapid Assessment Toolkit. The World Bank, Washington DC.

Elkan, W. 1988. Entrepreneurs and Entrepreneurship in Africa. The World Bank Research Observer 3(2): 171-188.

Esquivel, V., Sweetman, C. 2016. Gender and the Sustainable Development Goals. Gender and Development 24(1): 1-8.

Fanthorpe, R. 2007. BRACE (Building Resilience and Community Engagement) Institutional Survey. Unpublished report, Concern Worldwide, June.

Fisher, E., Mwaipopo, R., Mutagwaba, W., Nyange, D., Yaron, G. 2009. "The ladder that sends us to wealth": Artisanal mining and poverty reduction in Tanzania. Resources Policy 34: 32-38.

Frey, D.F. 2017. Economic growth, full employment and decent work: the means and ends in SDG 8. The International Journal of Human Rights 21(7): 1164-1184.

Galli, A., Durovic, G., Hanscom, L., Knezevic, J. 2018. Think globally, act locally: Implementing the sustainable development goals in Montenegro. Environmental Science \& Policy 84: 159-169.

Garrett, N. 2008. Artisanal Cassiterite Mining and Trade in North Kivu: Implications for Poverty Reduction and Security. Report prepared for the Communities and Artisanal and Small-Scale Mining (CASM) Initiative, Washington DC.

Geenen, S. 2014. Dispossession, displacement and resistance: artisanal miners in a gold concession in South-Kivu, Democratic Republic of Congo. Resources Policy 40: 90-99.

Gelb, A., Meyer, C.J., Ramachandran, V., Wadhwa, D. 2017. Can Africa Be a Manufacturing Destination? Labor Costs in Comparative Perspective. Center for Global Development Working Paper 466, Center for Global Development, Washington DC.

Government of Liberia. 2010. Regulations Governing Exploration Under a Mineral Exploration License of the Republic of Liberia ('Exploration Regulations'). Government of Liberia, Monrovia.

Hallward-Driemeier, M., Hasan, T. 2013. Empowering Women: Legal Rights and Economic Opportunities in Africa. The World Bank, Washington DC. 
Hayes, K., Perks, R. 2012. Women in the artisanal and small-scale mining sector of the democratic Republic of the Congo, pp. 546-561, in High-Value Natural Resources and Post-Conflict Peacebuilding (ed. P. Lujala), Routledge, New York.

Hentschel, T., Hruschka, F., Priester, M. 2002. Global Report on Artisanal and Small-Scale Mining, Minerals Mining and Sustainable Development (MMSD) Project. International Institute for Environmental Development, London.

Hilson, G. 2002. An overview of land use conflicts in mining communities. January 2002. Land Use Policy 19(1):65-73.

Hilson, G. 2009. Small-scale mining, poverty and economic development in sub-Saharan Africa: An overview. Resources Policy 34(1-2): 1-5.

Hilson, G. 2010. 'Once a Miner, Always a Miner': Poverty and Livelihood Diversification in Akwatia, Ghana. Journal of Rural Studies 26(3): 296-307.

Hilson, G. 2012. Poverty traps in small-scale mining communities: The case of sub-Saharan Africa. Canadian Journal of Development Studies 33(2): 180-197.

Hilson, G. 2018. Why is there a large-scale mining 'bias' in sub-Saharan Africa? Land Use Policy (accepted for publication). http://dx.doi.org/10.1016/j.landusepol.2017.02.013.

Hilson, G., and Garforth, C.J. 2013. 'Everyone now is concentrating on the mining': Drivers and Implications of Changing Agrarian Patterns in the Eastern Region of Ghana. The Journal of Development Studies 49(3): 348-362.

Hilson, G., Hilson, A., Maconachie, R. 2018. Opportunity or necessity? Conceptualizing entrepreneurship at African small-scale mines. Technological Forecasting and Social Change 131: 286-302

Hilson, G. and Maconachie, R. 2017. Formalising artisanal and small-scale mining: insights, contestations and clarifications. Area 49(4): 443-451

Hilson, G., Hilson, A., Maconachie, R., McQuilken, J. \& Goumandakoye, H. 2017. Artisanal and smallscale mining (ASM) in Sub-Saharan Africa: re-conceptualizing formalization and 'illegal' activity. Geoforum 83: 80-90.

Hinton, J. 2005. The Millennium Development Goals and Small-Scale Mining. The World Bank, Washington DC.

Hinton, J. 2005. The Millennium Development Goals and Small-Scale Mining. The World Bank, Washington DC.

Hinton, J., Veiga, M.M., Beinhoff, C. 2003. Women and Artisanal Mining: Gender Roles and the Road ahead, p. 149-188, AA. Balkema, the Netherlands.

Ighobor, K. 2015. Sustainable Development Goals are in sync with Africa's priorities. AfricaRenewal 29(3): 3-5. 
Intergovernmental Forum on Mining, Minerals, Metals and Sustainable Development (IGF). (2017). Global Trends in Artisanal and Small-scale Mining (ASM): A Review of key Numbers and Issues. International Institute for Sustainable Development, Winnipeg.

International Labour Office (ILO). 1999. Social and labour issues in small-scale mines. Report for discussion at the Tripartite Meeting on Social and Labour Issues in Small-scale Mine, International Labour Office, Geneva.

International Labour Office (ILO). 2009. The informal economy in Africa: Promoting transition to formality: Challenges and strategies. International Labour Office, Geneva.

International Labour Office (ILO) 2017. Towards a better future for women and work: Voices of women and men. International Labour Office, Geneva.

International Labour Office (ILO). 2018. World Employment Social Outlook. International Labour Department, International Labour Office, Geneva.

International Monetary Fund (IMF). 2017. Regional Economic Outlook Sub-Saharan Africa: Restarting the Growth Engine. International Monetary Fund, Washington DC.

International Institute for Sustainable Development (IISD). 2016. Sustainable Development Goals: IISD Perspectives on the 2030 Agenda for Sustainable Development. International Institute for Sustainable Development, Winnipeg

International Trade Union Conference (ITUC). 2011. Violence against women in Eastern Democratic Republic of Congo: Whose responsibility? Whose complicity? International Trade Union Conference, Brussels.

Kabadaki, K. 1994. Rural African women and development. 1994. Social Development Issues 16(2): 2335.

Kamlongera, P. J. 2011. Making the poor 'poorer' or alleviating poverty? Artisanal mining livelihoods in rural Malawi. Journal of International Development 23: 1128-1139.

Kelly, J.T.D., King-Close, A., Perks, R. 2014. Resources and resourcefulness: Roles, opportunities and risks for women working at artisanal mines in South Kivu, Democratic Republic of the Congo. Futures, 62, pp. 95-105.

Kim. E.M., 2017. Gender and the Sustainable Development Goals. Global Social Policy 17(2): 239-244.

Kumar, R., Amaratunga, D. 1994. Government policies towards small-scale mining. Resources Policy 20(1): 15-22.

Labonne, B. 1996. Artisanal mining: an economic stepping stone for women. Natural Resources Forum 20(2): 117-122.

Labonne, B. 1994.Small- and medium-scale mining: The Harare seminar and guidelines. Natural Resources Forum 18(1): 13-16.

Lahiri-Dutt, K. 2015. The Feminisation of Mining. Geography Compass 9(9): 523-541. 
Maconachie, R. 2011. Re-agrarianising livelihoods in post-conflict Sierra Leone? Mineral wealth and rural change in artisanal and small-scale mining communities. Journal of International Development 23: 1054-1067.

Maconachie, R. 2008. New agricultural frontiers in post-conflict Sierra Leone?: exploring institutional challenges for wetland management in the Eastern Province. Journal of Modern African Studies 46(2): 235-266.

Maconachie, R., Binns, T. 2007. 'Farming miners' or 'mining farmers'? diamond mining and rural development in post-conflict Sierra Leone. Journal of Rural Studies 23(3) 367-380.

Maconachie, R., Hilson, G. 2018. 'The war whose bullets you don't see': Diamond digging, resilience and Ebola in Sierra Leone. Journal of Rural Studies 61: 110-122.

Maconachie, R., Hilson, G. 2011. Artisanal gold mining: A new frontier in post-conflict Sierra Leone? The Journal of Development Studies. 47(4): 595-616.

Maclin, B.J., Kelly, J.T.D., Perks, R., Vinck, P., Pham, P. 2017. Moving to the mines: Motivations of men and women for migration to artisanal and small-scale mining sites in Eastern Democratic Republic of the Congo. Resources Policy 51: 115-122.

MacNaughton, G. 2017. Vertical inequalities: are the SDGs and human rights up to the challenges? The International Journal of Human Rights 21(7): 1050-1072.

Malpeli, K.C., Chirico, P.G. 2013. The influence of geomorphology on the role of women at artisanal and small-scale mine sites. Natural Resources Forum 37(1): 43-54.

Mbambi, A.M., Kandolo, L. 2016. Life at the bottom of the chain: Women in Artisanal Mines in DRC. Women's International League of Peace and Freedom.

McQuilken, J. Hilson, G. 2016. Artisanal and small-scale gold mining in Ghana: Evidence to inform an 'action' dialogue. Country Report, International Institute for Environment and Development, London.

Natural Resources Canada (NRC). 1995. Sustainable Development and Minerals and Metals. Minerals Strategy Branch, Minerals and Metals Sector, Natural Resources Canada, Ottawa.

Noetstaller, R. 1987. Small-Scale Mining: A Review of the Issues. World Bank Technical Paper Number 75. Industry and Finance Series. The World Bank, Washington D.C.

Olayide, P.B., Olawoye, J.E., Olayide, O.E. 2013. Gender Dimensions of Rural Livelihoods in Artisanal and Small-Scale Mining in Itesiwaju Area of Oyo State, Nigeria. African Journal of Sustainable Development 3(1): 72-87.

Organization of Economic Cooperation and Development (OECD). African Development Dynamics 2018. Organization of Economic Cooperation and Development (OECD), Paris.

Osirim, M.J. 1993. The state of women in the Third World: the informal sector and development in Africa and the Caribbean. Social Development Issues 14(2-3): 74-87.

Pedro, A.M. 2006. Mainstreaming Mineral Wealth in Growth and Poverty Reduction Strategies. Minerals and Energy 21(1): 2-16. 
Pickering, H., Kajura, E., Katongole, G., Whitworth, J. 1996. Women's groups and individual entrepreneurs. Focus on Gender 4(3): 56-60.

Pjipers, R. 2011. When Diamonds Go Bust: Contextualising Livelihood Changes in Rural Sierra Leone. Journal of International Development 23(8): 1068-1079.

Rickard, S., Treasure, W., McQuilken, J., Mihaylova, A., Baxter, J. 2017. Women in Mining, Can a mining law unlock the potential of women? Adam Smith International and International Women in Mining, London.

Rustad, S.A., Østby, G., Nordås, R. 2016. Artisanal mining, conflict, and sexual violence in Eastern DRC. The Extractive Industries and Society 3(2): 475-484.

Ruzvidzo, T. 2015. African Women in Artisanal and Small-Scale Mining. African Minerals Development Centre, United Nations Economic Commission for Africa, Addis Ababa.

Saiz, I., Donald, K. 2017. Tackling inequality through the Sustainable Development Goals: human rights in practice. The International Journal of Human Rights 21(7): 1029-1049.

Scott, J. 2014. Encyclopaedia of Gender and Mining: Key Initiatives, Best Practices and Actors. GIZ, Berlin.

Spiegel, S. 2015. Shifting Formalization Policies and Re-Centralizing Power: The Case of Zimbabwe's Artisanal Gold Mining Sector. Society \& Natural Resources 28(5): 543-558.

Spring, A., McDade, B. (eds.) 1998 African Entrepreneurship: Theory and Reality. University Press of Florida, Gainesville.

Stoner, C., Fry, F. 1982. The Entrepreneurial Decision: Dissatisfaction or Opportunity? Journal of Small Business Management 20(2): 39-44.

Traore, P.A. 1994. Constraints on small-scale mining in Africa. Natural Resources Forum 18(3): 207212.

United Nations (UN). 1996. Recent developments in small-scale mining. Natural Resources Forum 20(3): 215-225.

United Nations Conference on Trade and Development (UNCTAD). 2015. State of Commodity Dependence 2014. United Nations Conference on Trade and Development (UNCTAD), Geneva.

United Nations Development Program (UNDP). 2015. Human Development Report 2015: Work for Human Development. UNDP, New York.

United Nations Development Program (UNDP). 2016a. Mapping Mining to the Sustainable Empowered lives. Resilient nations. Development Goals: An Atlas. United Nations Development Program, New York.

United Nations Development Program (UNDP). 2016b. Human Development Report 2016: Human Development for Everyone. United Nations Development Program, New York. 
United Nations Development Program (UNDP). 2016c. Roadmap for Localizing the SDGs: Implementation and Monitoring at Subnational Level. United Nations Development Program, New York.

United Nations Economic Commission for Africa (UNECA). 1988. African Women's Work in the Informal Sector. United Nations Economic Commission for Africa (UNECA), Addis Ababa.

United Nations Economic Commission for Africa (UNECA). 2003. Report on Selected Themes in Natural Resources Development in Africa: Artisanal and Small-Scale Mining and Technology Challenges in Africa. United Nations Economic Commission for Africa and African Union, Addis Ababa, Ethiopia.

United Nations Economic Commission for Africa (UNECA). 2004. Economic Report on Africa 2004: Unlocking Africa's Trade Potential. United Nations Economic Commission for Africa, Addis Ababa.

United Nations Economic Commission for Africa (UNECA). 2012. The African Minerals Development Centre Business Plan. United Nations Economic Commission for Africa, Addis Ababa.

United Nations Economic Commission for Africa (UNECA). 2017a. Africa Mining Vision: Africa Minerals Governance Framework. United Nations Economic Commission for Africa, Addis Ababa.

United Nations Economic Commission for Africa (UNECA). 2017b. 2017 Africa Sustainable Development Report: Tracking Progress on Agenda 2063 and the Sustainable Development Goals. United Nations Economic Commission for Africa, Addis Ababa.

United Nations Economic Commission for Africa (UNECA). 2017c. Building Capacity for Environmental Sustainability in Small Scale Mining in Africa. United Nations Economic Commission for Africa, Addis Ababa.

United Nations Environment Program (UNEP), 2012. Analysis of Formalization Approaches in the Artisanal and Small-Scale Gold Mining Sector Based on Experience in Ecuador, Mongolia, Peru, Tanzania, and Uganda. United Nations Environment Program, Nairobi.

Valiana, S. 2015. The Africa Mining Vision: A Long Overdue Feminist Critique. WoMin Analytical Paper 16, WoMin, Johannesburg.

Van Bockstael, S. 2014. The persistence of informality: Perspectives on the future of artisanal mining in Liberia. Futures 62: 10-20.

Valiana, S. The Africa Mining Vision: A Long Overdue Ecofeminist Critique. WoMin Analytical Paper 16, WoMin, Johannesburg.

Verbrugge, B. 2016. Voices from below: Artisanal- and small-scale mining as a product and catalyst of rural transformation. Journal of Rural Studies 47: 108-116.

Verick, S. 2006. The Impact of Globalization on the Informal Sector in Africa. United Nations Economic Commission for Africa, Addis Ababa.

Wels, T.A., 1983. Small-Scale mining - the forgotten partner. Transactions of the Institution of Mining and Metallurgy 92(1): A19-A27.

Weldegiorgis, F. Lawson, L., Verbrugge, H. 2018. Intergovernmental Forum on Mining, Minerals, Metals and Sustainable Development (IGF). Women in Artisanal and Small-Scale Mining: Challenges 
and opportunities for greater participation. International Institute for Sustainable Development, Winnipeg.

Werthmann, K. 2009. Working in a boom-town: Female perspectives on gold-mining in Burkina Faso. Resources Policy 34(1-2): 18-23.

Wilson, J. 2016. The Village that Turned to Gold: A Parable of Philanthrocapitalism. Development and Change 47(1): 3-28.

Winkler, I.T., Williams, C. 2017. The Sustainable Development Goals and human rights: a critical early review. The International Journal of Human Rights 21(8): 1023-1028.

World Commission on Environment and Development (WCED). 1987. Our Common Future. World Commission on Environment and Development, Oxford University Press, Oxford, UK.

World Bank. 2010. Global Economic Prospects: Crisis, Finance, and Growth. The World Bank, Washington DC.

World Bank. 2014. Global Economic Prospects: Shifting Priorities, Building for the Future. The World Bank, Washington DC.

World Bank. 2016. Global Economic Prospects: Divergences and Risks. The World Bank, Washington DC.

World Bank. 2018. Global Economic Prospects: Broad-Based Upturn but for How Long? The World Bank, Washington DC.

World Bank. 2018. Women, Business and the Law 2018. The World Bank, Washington DC.

World Health Organization (WHO). 2016. Technical Paper 1: Environmental and Occupational Health Hazards Associated with Artisanal and Small-Scale Gold Mining. World Health Organization, Geneva.

Yakovleva, N. 2007. Perspectives on female participation in artisanal and small-scale mining: A case study of Birim North District of Ghana. Resources Policy 32: 29-41.

Zimbabwe Economic Policy Analysis and Research Unit (ZEPARU). 2016. Best Practices for Supporting Artisanal and Small-Scale Mining in Zimbabwe. Zimbabwe Economic Policy Analysis and Research Unit, Harare. 